\title{
THE PENICILLIN RECEPTOR IN STREPTOMYCES *
}

\author{
J.-M. Ghuysen, M. Leyh-Bouille, J.-M. Frère, J. Dusart, and \\ A. Marquet \\ Service de Microbiologie, Faculté de Médecine \\ Institut de Botanique, Université de Liège \\ Liège, Belgium
}

H. R. Perkins and M. Nieto $\dagger$

National Institute for Medical Research

Mill Hill, London N.W.7 1AA, England

\section{INTRODUCTION}

Penicillin kills bacteria by suppressing or decreasing the efficiency of the membrane-bound transpeptidase, which during the last steps of the wall synthesis catalyzes cross-linking between the peptide units of the nascent peptidoglycan and makes the polymer insoluble. ${ }^{1,2}$ In addition to this specific receptor, other penicillin-binding sites also occur within the bacterial membranes. ${ }^{3-\$}$ These sites, or at least most of them, seem to be irrelevant as far as peptidoglycan synthesis is concerned.4 Although involved in antibiotic specificity, they do not appear to be the killing target of penicillin.

At present, no transpeptidase has been isolated from bacterial membranes and characterized. For a long time, the technical limitation to such an achievement has resided in the lack of a suitable assay for transpeptidase activity. Cell-free particulate multienzyme preparations obtained from various bacteria were shown to catalyze the in vitro utilization of the nucleotide precursors UDP- $N$-acetylglucosamine and UDP- $N$-acetylmuramyl pentapeptide for the entire sequence of peptidoglycan synthesis, which includes the peptide crosslinking. ${ }^{9-15}$ These assays, however, were devised in such a way that they did not allow measurement of the transpeptidation reaction per se. Another approach was undertaken through a joint effort between our laboratories and was based on the development of well-defined systems of peptide donors and acceptors that could be used by bacterial transpeptidases for transpeptidation reactions and, hence, would allow these enzymes to be operative and tested independently of the preceding biosynthetic sequential reactions. Streptomyces sp were chosen as a model, because they had the property, probably unique in the bacterial world, of spontaneously excreting an enzyme that appeared to be a soluble form of the membrane-bound transpeptidase.

* This work was supported in part by grants (to J.M.G.) from the Fonds de la Recherche Fondamentale Collective (no. 1000), Brussels, Belgium and the Institut pour l'Encouragement de la Recherche Scientifique dans l'Industrie et l'Agriculture (nos. 1699 and 2013), Brussels, Belgium.

† Present address: Centro de Investigaciones Biologicas, Instituto de Biologia Celular, Madrid 6, Spain. 
THE DD-CaRboXYPEPTIDASE-TRANSPEPTIDASE SYSTEM IN Streptomyces STRAIN R61

\section{Structure of the Wall Peptidoglycan}

In Streptomyces $\mathrm{R} 1^{11}$ (as well as in strains $\mathrm{K} 11^{17}$ and albus $\mathrm{G}^{18}$ and in Clostridium perfringens $\left.{ }^{1 *}\right)$, the wall peptidoglycan is composed of $\mathrm{L}$-alanyl-Disoglutaminyl- $\left(\mathrm{L}_{1}\right)$-LL-diaminopimelyl- $\left(\mathrm{L}_{1}\right)-\mathrm{D}$-alanine tetrapeptides that are interlinked through an additional glycine residue that extends from the $\mathrm{C}$-terminal D-alanine of one peptide to the $\left(L_{2}\right)$ amino group of $L L$-diaminopimelic acid of another peptide. Because of this structure, the transpeptidation reaction in Streptomyces R61 must occur as shown in FIGURE 1.

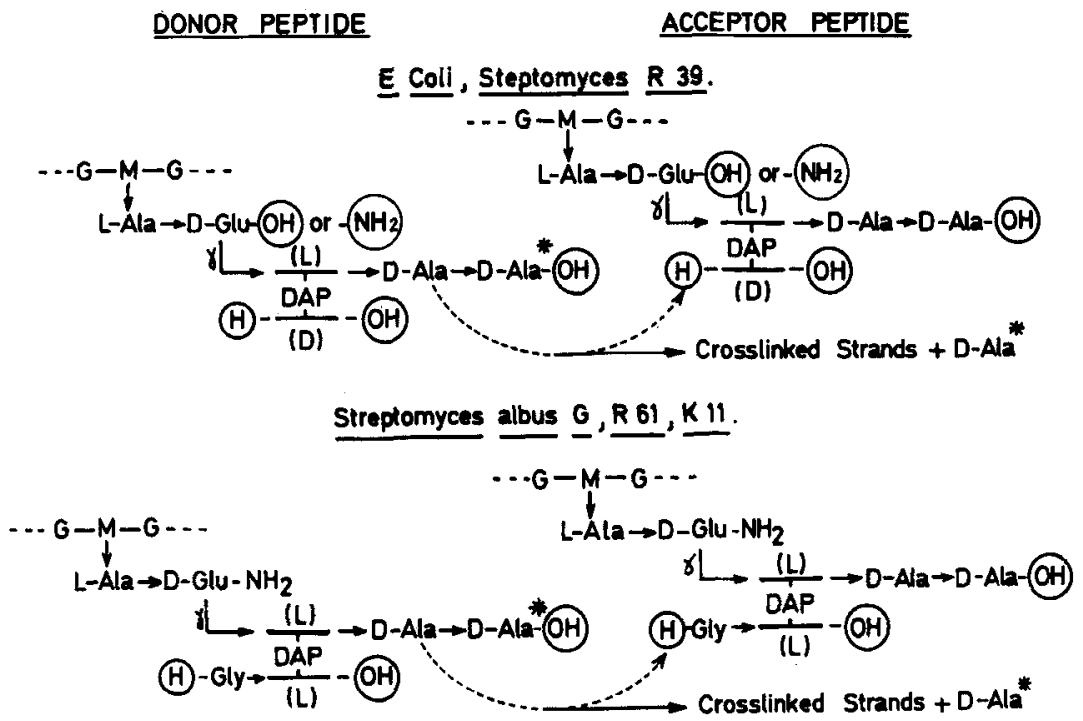

FIGURE 1. Transpeptidation reaction in various bacteria, G, $N$-acetylglucosamine; $\mathbf{M}, N$-acetylmuramic acid; DAP, diaminopimelic acid. The $\alpha$-carboxyl group of $\mathbf{D}-$ glutamic acid is free in Escherichia coli and is substituted by an amide in Streptomyces R39.

\section{Ac:-L-Lys-D-Ala-D-Ala and Gly-Gly as Substrates for Transpeptidation by Streptomyces R61}

Streptomyces R61 possesses a transpeptidase activity that catalyzes the transfer of $N^{\alpha}, N^{\epsilon}$-diacetyl-1.-lysyl-D-alanine from the tripeptide donor $N^{\alpha}, N^{\epsilon}$-diacetylL-lysyl-D-alanyl-D-alanine to the dipeptide acceptor glycylglycine, which yields free $\mathrm{D}$-alanine and the tetrapeptide $N^{\alpha}, N^{\epsilon}$-diacetyl-L-lysyl-D-alanylglycylglycine. This transpeptidase activity was located within the plasma membrane ${ }^{21}$ but was also excreted in the external medium during growth. ${ }^{16}$ With the membranebound enzyme, liberation of $\mathrm{D}$-alanine from the tripeptide donor was strictly 
dependent on the presence of the acceptor glycylglycine in the reaction mixture. The culture filtrate, however, could also hydrolyze the tripeptide donor alone into D-alanine and the dipeptide $N^{\alpha}, N^{\epsilon}$-diacetyl-L-lysyl-D-alanine; that is, it exhibited both a DD-carboxypeptidase activity and a transpeptidase activity. The only difference between the two reactions was that in transpeptidation the enzyme catalyzed a reaction with the free amino group of glycylglycine to complete peptide cross-linking, whereas in hydrolysis the enzyme catalyzed a reaction with water:

$$
\begin{aligned}
& \mathrm{Ac}_{2} \text {-L-Lys-D-Ala-D-Ala }+ \text { Gly-Gly } \rightarrow \text { D-Ala }+\mathrm{Ac}_{2} \text {-L-Lys-D-Ala-Gly-Gly, } \\
& \mathrm{Ac}_{2} \text {-L-Lys-D-Ala-D-Ala }+\mathrm{H}_{2} \mathrm{O} \rightarrow \text { D-Ala }+\mathrm{Ac}_{2} \text {-L-Lys-D-Ala. }
\end{aligned}
$$

It can be argued that integration of the enzyme in the hydrophobic environment of the membrane only allowed transpeptidation to occur, whereas water was accessible to the exocellular enzyme.

\section{Characterization of the R61 Membrane-Bound Transpeptidase

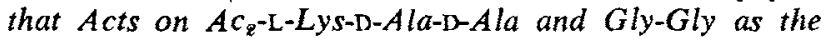 Physiological Transpeptidase}

The in vivo susceptibility of Streptomyces R61 toward a series of penicillins and cephalosporins ( $\mathrm{LD}_{50}$ values) was tested under conditions in which $\beta$ lactamase activity was not involved. The in vivo susceptibility was found to correlate well with the in vitro susceptibility of the membrane-bound transpeptidase toward the same antibiotics 21,22 (ID ${ }_{50}$ values, TABLE 1). Membranes isolated from Streptomyces $\mathrm{R} 61$ bound a maximum of 25 pmoles of [ ${ }^{14} \mathrm{C}$ ]benzylpenicillin per milligram of protein (as determined after treatment of the membranes with a large excess of $\left[{ }^{14} \mathrm{C}\right]$ benzylpenicillin and removal of the unbound antibiotic by washings with buffer). Pretreatment of the membrane by nonradioactive 6-aminopenicillanic acid, benzylpenicillin, ampicillin, or carbenicillin at concentrations equivalent to those that reduced by $50 \%$ the activity of the membrane-bound transpeptidase (i.e., the $\mathrm{ID}_{\tilde{0}}$ values) inhibited by $50 \%$ the uptake of $\left[{ }^{14} \mathrm{C}\right]$ benzylpenicillin. ${ }^{3 i}$

The above experiments did not establish whether the transpeptidase was the only binding site for penicillin. They demonstrated, however, that penicillins were competing for the same membrane component(s) and that the membranebound transpeptidase, as revealed by using the above tripeptide donor and dipeptide acceptor for transpeptidation reactions, was indeed the killing target of penicillin. $N^{\alpha}, N^{\epsilon}$-diacetyl-L-lysyl-D-alanyl-D-alanine was, therefore, an analog of the donor site, and glycylglycine was an analog of the glycyl-LI.-diaminopimelyl acceptor site involved in transpeptidation in vivo (FIGURE 1). One should also note that both the cross-linking accomplished by transpeptidation from the artificial donor-acceptor system and the cross-linking produced by transpeptidation in vivo resulted in the synthesis of the same D-alanylglycine linkage in an endo position (FIGURE 1). 


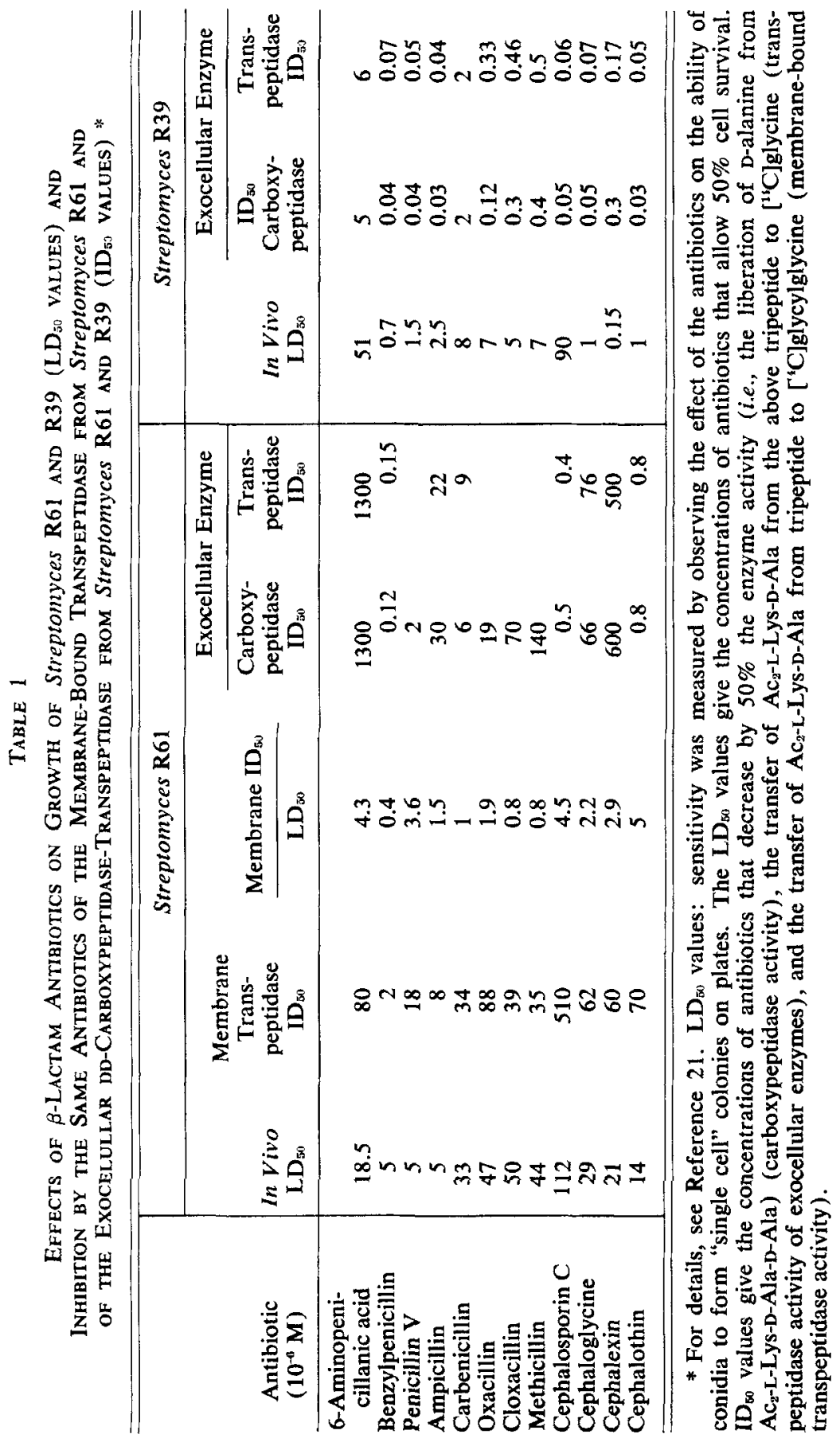




\section{Characterization of the Exocellular R61 Transpeptidase that Acts on $A c_{2}-\mathrm{L}-$ Lys-D-Ala-D-Ala and Gly-Gly as a Soluble Form of the Membrane-Bound Transpeptidase}

Urea ( $2 \mathrm{M}$, in the presence of $10 \mathrm{mM}$ ethylenediaminetetraacetate) solubilized the membrane-bound transpeptidase. Strikingly, the solubilized preparation exhibited carboxypeptidase activity, in addition to the transpeptidase activity. ${ }^{37}$ The enzyme released from the membrane has not yet been isolated, but the exocellular enzyme was purified to protein homogeneity. ${ }^{23}$ It consisted of a single polypeptide chain, with a molecular weight of 38,000 and an isoelectric point at $\mathrm{pH} 4.7$. The acid residues $(20 \%)$ outnumbered the basic ones $(5 \%)$. The protein contained about three half-cystine residues out of a total of 350 amino acid residues. Approximately $50 \%$ of the residues were nonpolar. The turnover number was 3500 molecules of D-alanine liberated from $N^{\alpha} . N^{\epsilon}$-diacetylL-lysyl-D-alanyl-D-alanine per molecule of enzyme per minute [carboxypeptidase assay, in $0.005 \mathrm{M}$ phosphate buffer $(\mathrm{pH} 7.5)]$. As observed with the ureatreated membrane enzyme, the purified exocellular enzyme was shown to function either as carboxypeptidase or as transpeptidase; this depended upon the availability of nucleophiles $\left(\mathrm{H}_{2} \mathrm{O}\right.$ or Gly-Gly or other $\left.\mathrm{NH}_{2}-\mathrm{R}\right) .^{24-26}$ The proportion of the exocellular enzyme activity that could be channeled into the transpeptidation and the hydrolysis pathways depended upon the environmental conditions. ${ }^{26}$ Transpeptidation was increased and hydrolysis was decreased by increasing the $\mathrm{pH}$ of the reaction mixture and the concentration of acceptor in it (within certain limits). Replacement of part of the water of the reaction mixture by a solvent of low polarity [such as a mixture of water, ethylene glycol, and glycerol, 30:45:25 (v:v:v)] preferentially decreased the carboxypeptidase activity of the enzyme, so that transpeptidation then largely superseded hydrolysis. The specificity profile of the exocellular enzyme for acceptors (with

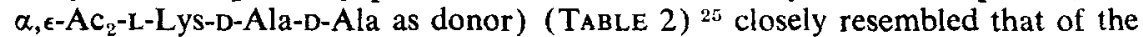
membrane-bound enzyme. ${ }^{21}$ Finally, irrespective of the penicillins and cephalosporins used, inhibition of the transpeptidase activity of the exocellular enzyme always occurred at those antibiotic concentrations that inhibited its carboxypeptidase activity ${ }^{21}$ (TABLE 1).

As a whole, the above experiments strongly suggested that the exocellular transpeptidase-DD-carboxypeptidase was a soluble form of the "physiological" membrane-bound transpeptidase. There were, however, quantitative differences between the two enzymes, especially with respect to their susceptibility to $\beta$ lactam antibiotics (TABLE 1). It could be argued that the enzyme conformation in the hydrophobic environment of the membrane was unlike that in an aqueous solvent and that the observed dissimilarities resulted from a change in orientation of one or more amino acid residues in or near the catalytic center(s) and/or penicillin binding site.

\section{Kinetics of Concomitant Transfer and Hydrolysis Reactions Catalyzed by the Exocellular R6I Enzyme}

From a theoretical analysis of the kinetic parameters of the various possible enzyme mechanisms in which bimolecular transfer reactions occur concomitantly with the hydrolysis of the donor molecule, it appeared that the ratios $v_{\mathrm{T}} / v_{\mathrm{Hy}}$ ( $\mathrm{T}$, transpeptidation; $\mathrm{Hy}$, hydrolysis) versus the concentration of the 
donor [D] and that of the acceptor [A] are the most useful parameters for making a choice of mechanism. ${ }^{2-}$ If the reactions occur randomly or proceed through an ordered mechanism in which the donor binds first to the enzyme, the ratio $v_{\mathrm{T}} / v_{\mathrm{Hy}}$ is independent of [D]. With mechanisms in which the acceptor

TABLE 2

TRANSPEPTIDATION BY EXOCELLULAR DD-CARBOXYPEPTIDASES FROM Streptomyces R61, K11, R39, AND albus G

\begin{tabular}{|c|c|c|c|c|c|}
\hline & \multirow{2}{*}{$\begin{array}{l}\text { Acceptor:Donor } \\
\text { Molar Ratio } \dagger\end{array}$} & \multicolumn{4}{|c|}{ Transpeptidation (\%) } \\
\hline & & R61 & K11 & R39 & S. albus $\mathrm{G}$ \\
\hline \multicolumn{6}{|l|}{$\alpha$-Amino Acids } \\
\hline \multirow[t]{2}{*}[{}^{11}\mathrm{C}]{$g l y c i n e$} & $1: 1$ & 13.7 & & & \\
\hline & $10: 1$ & 48 & 45 & 30 & 0 \\
\hline \multirow[t]{2}{*}{$D-\left[{ }^{14} \mathrm{C}\right]$ alanine } & $1: 1$ & 7.5 & & & \\
\hline & $10: 1$ & 50 & & 35 & 0 \\
\hline $\mathrm{L}-\left[{ }^{[4} \mathrm{C}\right]$ alanine & $10: 1$ & 0 & & 0 & \\
\hline \multirow[t]{2}{*}{ meso- $\left[{ }^{3} \mathrm{H}\right]$ diaminopimelic acid $*$} & $1: 1$ & 16.0 & 18.2 & 7.4 & \\
\hline & $10: 1$ & & 48 & 45 & 0 \\
\hline $\begin{array}{l}\text { Mono }\left[{ }^{14} \mathrm{C}\right] \text { acetyl-LL- } \\
\text { diaminopimelic acid }\end{array}$ & $1: 1$ & $\mathbf{0}$ & & & \\
\hline \multicolumn{6}{|l|}{ Dipeptides } \\
\hline \multirow[t]{2}{*}{ 1-[ $\left[{ }^{14} \mathrm{C}\right]$ glycylglycine } & $1: 1$ & 18.4 & & & 0 \\
\hline & $10: 1$ & & & 0 & 0 \\
\hline Glycyl-D- $\left[{ }^{14} \mathrm{C}\right]$ alanine & $1: 1$ & 3.6 & 4.0 & 0 & \\
\hline Glycyl-L- $\left[{ }^{\mathrm{ta}} \mathrm{C}\right]$ alanine & $1: 1$ & 25.5 & 24.6 & 0 & \\
\hline$\epsilon$-Glycyl- $\alpha$-acetyl-L- $\left[{ }^{3} \mathrm{H}\right]$ lysine & $1: 1$ & 18.2 & & 0 & 0 \\
\hline$\alpha$-Glycyl- $\alpha^{\prime}-\left[{ }^{14} \mathrm{C}\right]$ acetyl- & $0.56: 1$ & 4.8 & & 0 & 0 \\
\hline LL-diaminopimelic acid & $4.1: 1$ & 2.7 & & 0 & 0 \\
\hline D-Alanyl $\left[{ }^{14} \mathrm{C}\right]$ glycine & $1: 1$ & 3.6 & 3.4 & 0 & \\
\hline D-Alanyl-L- $\left[{ }^{14} \mathrm{C}\right]$ alanine & $1: 1$ & 2.6 & 2.1 & 0 & \\
\hline $\mathrm{D}$-Alanyl-D- $\left[{ }^{14} \mathrm{C}\right]$ alanine & $1: 1$ & 0.4 & & 0 & \\
\hline L-Alanyl-L- $\left[{ }^{14} \mathrm{C}\right]$ alanine & $1: 1$ & 0.2 & 0.2 & 0 & \\
\hline
\end{tabular}

* The D center of meso-diaminopimelic acid was the one that acted as a transpeptidation acceptor. ${ }^{.4}$

it The donor was diacetyl-L-lysyl-D-alanyl-D-alanine, $50 \mathrm{nmol}$, in a final volume of $30 \mu \mathrm{l}$. Incubation: $1 \mathrm{hr}, 37^{\circ} \mathrm{C}$. The values represent the percentage of the donor converted to the transpeptidation product $\mathrm{Ac}_{2}-\mathrm{L}-\mathrm{Lys}-\mathrm{D}-\mathrm{Ala}$-acceptor. For details, see Reference 25 .

binds first to the enzyme, the ratio $v_{\mathrm{T}} / v_{\mathrm{Fy}}$ is a function of [D], according to the equation

$$
\frac{v_{\Gamma}}{v_{\mathrm{Hy}}}=\frac{a+b[\mathrm{D}]}{c+d[\mathrm{D}]},
$$

where $a, b, c$, and $d$ are constants. Irrespective of the mechanisms involved in the reaction, the ratio $v_{\mathrm{T}} / v_{\mathrm{Hy}}$ is directly proportional to [A], except if an additional acceptor binding site occurs on the enzyme, which leads to the formation of an [enzyme-acceptor ${ }_{2}$-donor] complex nonproductive for transpeptidation and an [enzyme- $\mathrm{H}_{2} \mathrm{O}$-acceptor-donor] complex that remains pro- 

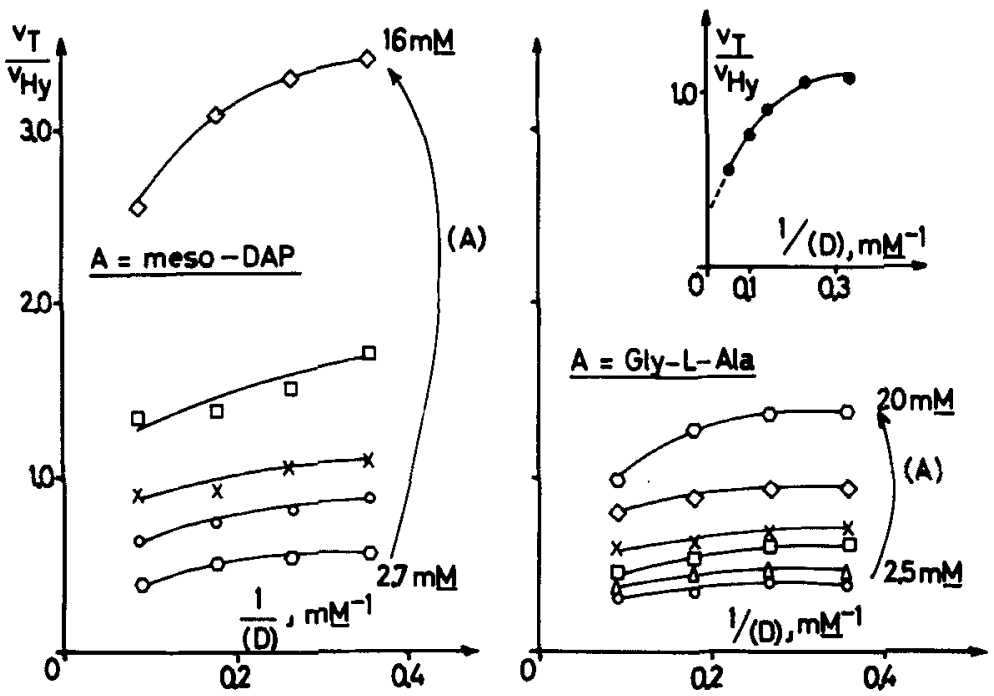

FIGURE 2. Concomitant transfer and hydrolysis reactions catalyzed by the exocellular R61 enzyme. Plots of $v_{\mathfrak{x}} / v_{\mathrm{H} y}$ vs $1 /$ [D] for various concentrations of acceptor. Tripeptide donor and acceptor were incubated at $37^{\circ} \mathrm{C}$ in $4 \mathrm{mM}$ sodium phosphate buffer ( $\mathrm{pH} \mathrm{7.2)} \mathrm{(final} \mathrm{volume}=35 \mu \mathrm{l}$ ) with R61 enzyme. With Gly-L-Ala, 125 units of enzyme were used. With meso-diaminopimelic acid, 250 units were used, and the reaction mixture was $32 \mathrm{mM}$ in $\mathrm{NaCl}$. Maximal utilization of the tripeptide donor was $20-25 \%$. The reaction rates were similar with both acceptors and were linear with time. Concentrations of meso-diaminopimelic acid were: $0,2.7 ; 0,4 ; \times$, $5.3 ; \square, 8 ;$ and $\diamond, 16 \mathrm{mM}$. Concentrations of Gly-L-Ala were: $0,2.5 ; \Delta, 3.5 ; \square$, $5 ; \times, 6.7 ; \diamond, 10$; and $\bigcirc, 20 \mathrm{mM}$. For the curve enclosed in the right upper part of the Figure, the highest concentration of tripeptide donor utilized was increased up to $19.3 \mathrm{mM}$; Gly-L-Ala $(20 \mathrm{mM})$ was incubated with 80 units of enzyme for $80 \mathrm{~min}$. (From Frère et al..$^{30}$ By permission of The Biochemical Journal.)

ductive for hydrolysis. In the latter case, the ratio $v_{\mathrm{T}} / v_{\mathrm{Hy}}$ is a function of [A], according to the equation

$$
\begin{aligned}
\frac{v_{\mathrm{T}}}{v_{\mathrm{IIy}}} & =\frac{e[\mathrm{~A}]}{f[\mathrm{~A}]+g} \\
\text { i.e., } \frac{v_{\mathrm{Iry}}}{v_{\mathrm{T}}} & =\frac{f}{e}+\frac{g}{e[\mathrm{~A}]}, \text { where } e, f, \text { and } g \text { are also constants. }
\end{aligned}
$$

When $N^{a}, N^{\varepsilon}$-diacetyl-L-lysyl-D-alanyl-D-alanine (i.e., the donor) and either meso-diaminopimelic acid or glycyl-L-alanine (i.e., the acceptor) were exposed to the exocellular R61 enzyme, initial rate measurements showed that both acceptors behaved as noncompetitive inhibitors of the hydrolysis reaction. ${ }^{26}$ Furthermore, the ratios $v_{\mathrm{T}} / v_{\mathrm{Hy}}$ were not independent of [D] but significantly decreased as [D] increased (FIGURE 2), which suggested an ordered pathway mechanism in which the acceptor molecule bound first to the enzyme: 


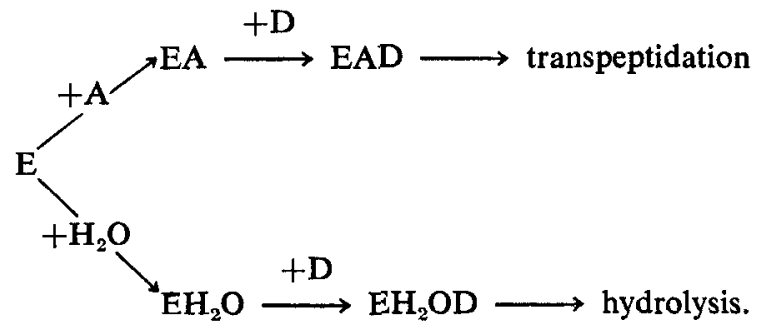

At any concentration of tripeptide donor, the ratio $v_{\mathrm{T}} / v_{\mathrm{Hy}}$ was directly proportional to the concentration of the acceptor meso-diaminopimelic acid (FIGURE 3 ). In marked contrast, high concentrations of glycyl-L-alanine inhibited the transpeptidation pathway (FIGURE 3 ), in a way that fitted the equation

$$
\frac{v_{\mathrm{Hy}}}{v_{\mathrm{T}}}=\frac{f}{e}+\frac{g}{e[\mathrm{~A}]},
$$

(FIGURE 4) which suggested a more complex mechanism:

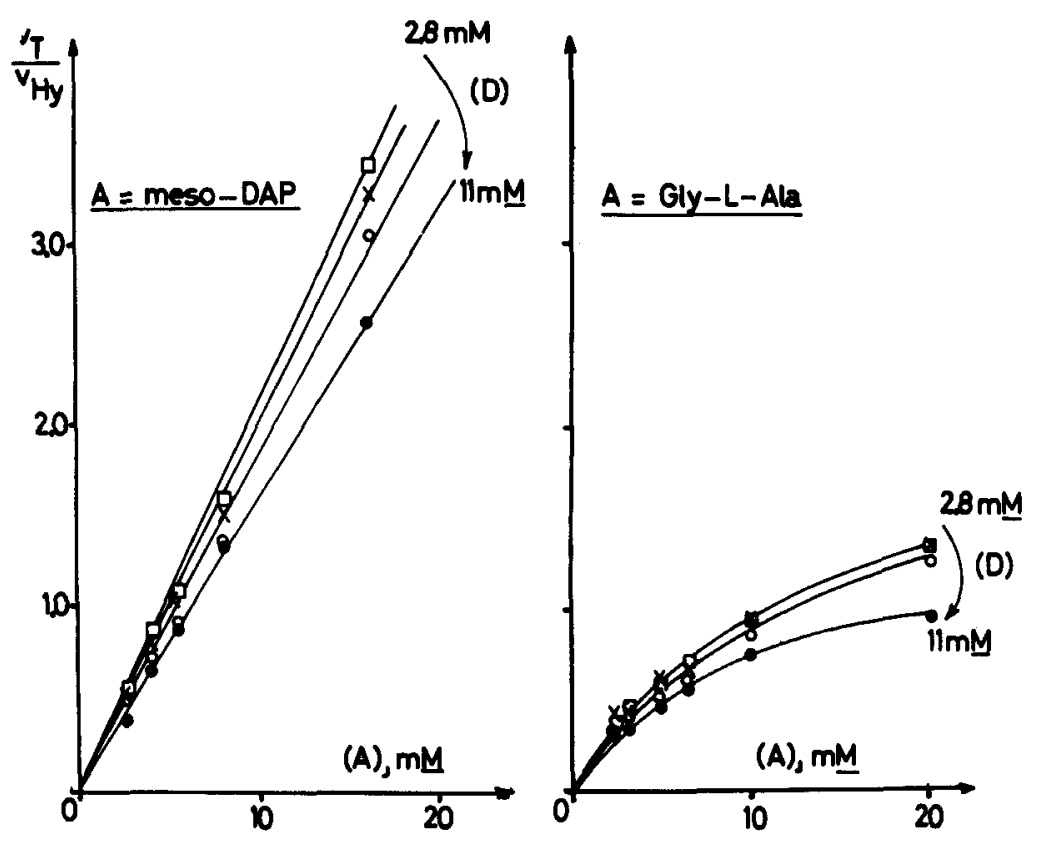

Figure 3. Concomitant transfer and hydrolysis reactions catalyzed by the exocellular R61 enzyme. Plots of $v_{\mathrm{r}} / v_{\mathrm{H} y}$ vs [A] for various concentrations of tripeptide donor. For conditions, see Figure 2. Concentrations of acceptor (either mesodiaminopimelic acid or Gly-L-Ala were: $\square, 2.8 ; \times, 3.7 ; 0,5.5$; and $0,11 \mathrm{mM}$. (From Frère et al. ${ }^{26}$ By permission of The Biochemical Journal.) 


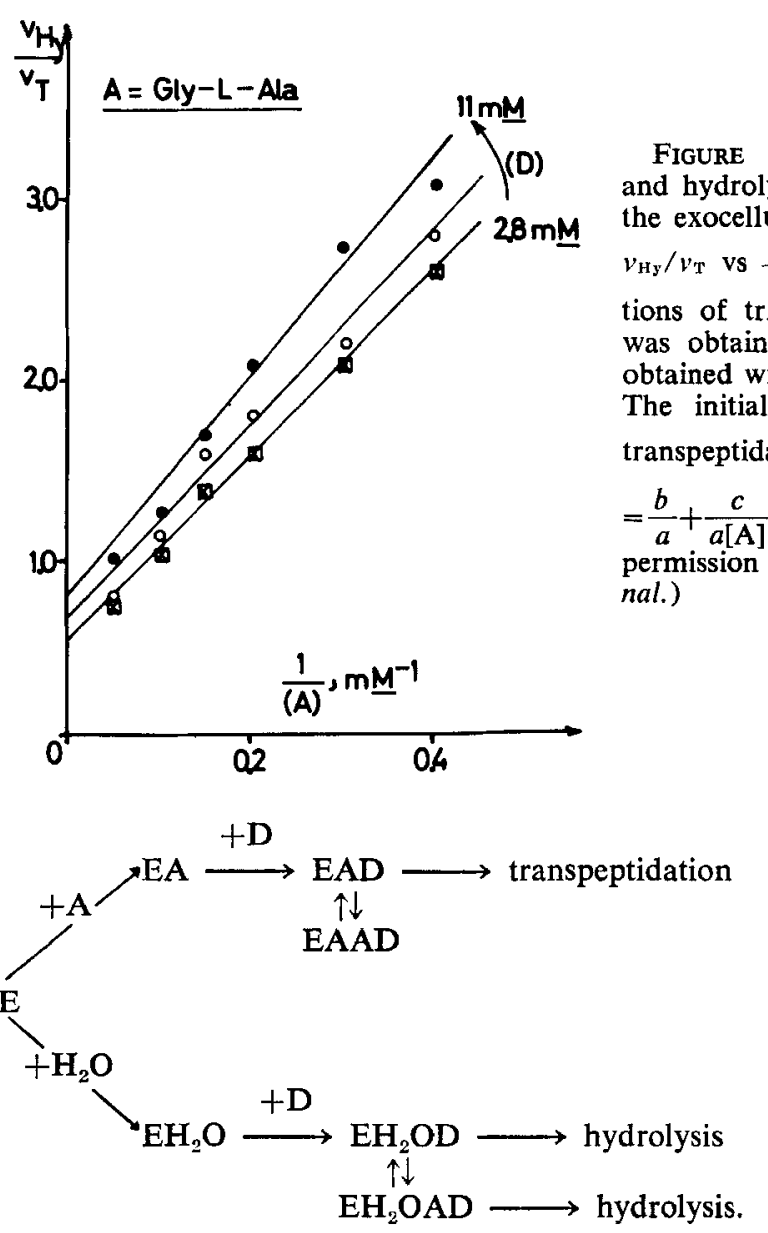

Inhibition of transpeptidation by an excess of acceptors was also observed with peptides other than glycyl-L-alanine (legend of TABLE 2) and especially with the natural peptide that undergoes transpeptidation in Streptomyces R61, that is, L-alanyl-D-isoglutaminyl- $\left(\mathrm{L}_{1}\right)$;glycyl- $\left(\mathrm{L}_{2}\right)$;LL-diaminopimelic acid. ${ }^{37}$ It is possible that this feature reflects a control mechanism involved in the functioning of the enzyme in vivo. In the above proposed mechanisms, $\mathrm{H}_{2} \mathrm{O}$ was considered as an alternative nucleophile acceptor. One should note, however, that the kinetics were not incompatible with nonsymmetrical pathways, in which the acceptor would bind first to the enzyme in the transpeptidation reaction, whereas the donor would bind first to the enzyme in the hydrolysis reaction.

\section{The Exocellular R61 Enzyme as a Model for Carboxypeptidase Activity}

In carboxypeptidase assays [peptide donor: $-\mathrm{R}_{3}-\mathrm{R}_{2}-\mathrm{R}_{1}(\mathrm{OH})+\mathrm{H}_{2} \mathrm{O} \rightarrow$ $-R_{3}-R_{2}(\mathrm{OH})+R_{1}$, the enzyme exhibited a considerable specificity for peptides that ended in the tripeptide sequence $L-R_{3}-D-A l a-D(O H)$ and for the 
occurrence of a long aliphatic side chain at the $L-R_{3}$ position ${ }^{16,} 28$ (TABLE 3 ). The C-terminal D-residue was preferentially D-alanine. Peptides that were good substrates (such as $N^{\alpha}, N^{\epsilon}$-diacetyl-L-lysyl-D-alanyl-D-alanine) had $K_{m}$ values $(10-15 \mathrm{mM})$ as high as the poor substrates, but the good substrates had much higher $V_{\max }$ values. The enzyme thus appeared to possess a binding surface that was not very specific, as it was even able to bind molecules that were only remotely analogous to the substrate. It was suggested that the alignment of the catalytic groups induced on binding would be incorrect or unfavorable for poor substrates, which would thus decrease the $V_{\operatorname{mnx}}$ greatly or even prevent enzyme action.

The carboxypeptidase activity of the enzyme was inhibited by peptide analogs of the standard substrate $N^{\alpha}, N^{\epsilon}$-diacetyl-L-lysyl-D-alanyl-D-alanine ${ }^{29}$ (TABLE 4). Kinetically, the inhibition by acetyl-D-alanyl-D-aspartic acid was competitive. These studies (TABLES $3 \& 4$ ) indicated that residues $R_{2}$ and $R_{1}$ were mainly concerned with the binding to the enzyme, whereas size, shape, and charge on residue $L-R_{3}$ appeared to be decisive for enzymatic activity. Acetyl-racemic-cyclodiaminoadipic acid was an inhibitor (TABLE 4), and its binding to the enzyme was stronger than that of acetyl-D-alanyl-D-alanine (as judged by the inhibition caused by both of them), which suggested that the enzyme combined only with peptides that have a cis configuration in the C-terminal amide linkage. A possible sequence of events that lead to hydrolysis

\section{TABLE 3}

Influence of the Length, Size, and Charge of the Side Chain OF THE L-R Residue ON CARBOXYPEPTIDASE ACTIVITY of Exocellular Streptomyces ENzymes (RELEASE of the C-TERMINAL D-ALANINE) *

\begin{tabular}{|c|c|c|c|c|}
\hline \multirow[b]{2}{*}{ Substrates $\dagger$} & \multicolumn{4}{|c|}{ Activity (\%) $\ddagger$} \\
\hline & $\begin{array}{c}\text { R61 } \\
\text { Enzyme }\end{array}$ & $\begin{array}{c}\text { K11 } \\
\text { Enzyme }\end{array}$ & $\begin{array}{c}\text { R39 } \\
\text { Enzyme }\end{array}$ & $\begin{array}{l}\text { S. albus G } \\
\text { Enzyme }\end{array}$ \\
\hline 1. Ac-L-Ala-D-Ala-D-Ala & 1.4 & 1.2 & 0.2 & 0.8 \\
\hline 2. $\mathbf{R}^{\mathrm{a}}$-L-homoSer-D-Ala-D-Ala & 3 & 2 & 6.6 & 5 \\
\hline 3. $N^{\alpha}, N^{\gamma}-A c_{2}=\mathrm{L}-\mathrm{DAB} \&$-D-Ala-D-Ala & 8.5 & $\overline{9}$ & 15.5 & 55 \\
\hline 4. $N^{\alpha}, N^{\delta}-\mathrm{Ac}_{2}-\mathrm{L}-\mathrm{Orn}-\mathrm{D}-\mathrm{Ala}-\mathrm{D}-\mathrm{Ala}$ & 45 & 55 & 83 & 55 \\
\hline 5. $N^{\alpha}, N^{e}-\mathrm{Ac}_{2}-\mathrm{L}-\mathrm{L}$ ys-D-Ala-D-Ala & 100 & 100 & 100 & 100 \\
\hline 6. $\mathrm{N}^{\alpha}-A c-L-L$ ys-D-Ala-D-Ala & 0.5 & 0.3 & 730 & 1 \\
\hline 7. $\mathrm{R}^{\mathrm{b}}(\mathrm{L})$-meso-DAP-(L)-D-Ala-D-Ala & 0.5 & 1 & 400 & 8 \\
\hline $\begin{array}{l}\text { 8. R } \\
\mathrm{R}_{\text {Gly }}^{\mathrm{C}} \mathrm{L}-\mathrm{LyS}-\mathrm{D}-\mathrm{Ala}-\mathrm{D}-\mathrm{Ala}\end{array}$ & 80 & 100 & 340 & 11 \\
\hline
\end{tabular}

* For details, see Ref. 16, 17, 28 and 32 .

$\uparrow \mathbf{R}^{\mathrm{a}}=$ UDP-MurNAc-Gly-D-Glu- $\gamma ; \mathbf{R}^{\mathrm{b}}=$ UDP-MurNAc-L-Ala-D-Glu- $\gamma ; \mathbf{R}^{\mathrm{c}}=\mathrm{N}^{\mathrm{\alpha}-}$

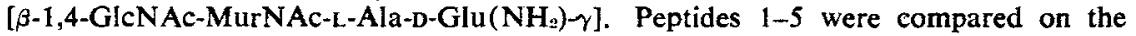
basis of nequiv of D-Ala liberated per milligram of enzyme per hour at $37^{\circ} \mathrm{C}$ (peptide concentration: $0.45 \mathrm{mM}$. Peptides 5-8 were compared on the basis of enzyme efficiency (i.e., $V_{\max /} K_{m}$ ).

¥ Turnover numbers (molecule D-Ala released $/ \mathrm{min} / \mathrm{molecule}$ enzyme) for standard peptide $A c_{2}$-L-Lys-D-Ala-D-Ala $=3500$ for purified R61 enzyme (MW 38,000$)^{23}$ and 850 for purified R39 enzyme (MW 55,000)."?

$\S \mathrm{DAB}$, diaminobutyric acid. 
TABLE 4

Activity of the Exocellular R61 and $S$. albus $G$ Enzymes in the Presence OF INHIBITORS (CARBOXYPEPTIDASE ASSAY) *

\begin{tabular}{|c|c|c|c|c|}
\hline \multirow[b]{2}{*}{ Compound } & \multirow[b]{2}{*}{$\begin{array}{l}\text { Activity as } \\
\text { Substrate \% }\end{array}$} & \multirow{2}{*}{$\begin{array}{c}\begin{array}{c}\text { Molar } \\
\text { Ratio } \\
\text { Inhibitor }\end{array} \\
\text { Substrate }\end{array}$} & \multicolumn{2}{|c|}{$\%$ Inhibition } \\
\hline & & & $\begin{array}{c}\text { R61 } \\
\text { Enzyme }\end{array}$ & $\begin{array}{c}\text { S. albus } \mathrm{G} \\
\text { Enzyme }\end{array}$ \\
\hline Ac $c_{2-L}-$ Lys-D-Ala-D-Ala & 100 & & 0 & 0 \\
\hline Ac-D-Ala-D-Ala & $0-1$ & 10 & 10 & $10-20$ \\
\hline Ac-D-Ala-D-Glu & 0 & 10 & 25 & 88 \\
\hline$\alpha \epsilon-S u c_{2}-\mathrm{L}-\mathrm{L}$ ys-D-Ala-D-Glu & $\mathbf{0}$ & 10 & $32-46$ & $88-96$ \\
\hline Ac-Gly-D-Ala-D-Glu & 0 & $10-12$ & 25 & 84 \\
\hline Ac-D-Äla-D-Asp & 0 & $10-11$ & 38 & 59 \\
\hline $\mathrm{Ac}_{2}-\mathrm{L}-\mathrm{L}$ ys-D-Glu-D-Ala & 0 & 14 & $34-36$ & 87 \\
\hline$\alpha$-Ac-L-Lys-D-Glu-D-Ala & 0 & 11.6 & $33-35$ & 67 \\
\hline $\begin{array}{l}\text { Acetyl-racemic-cyclodiaminoadipic } \\
\text { acid }\end{array}$ & 0 & 17 & 26 & 52 \\
\hline
\end{tabular}

* For details, see Reference 29.

was proposed.29 According to the model, the enzyme would select the small proportion of $c i s$ isomer, hence displacing the configuration equilibrium. The free enthalpy of binding would be mainly provided by the interaction of the two C-terminal residues, whereas the side chain of the $L-R_{3}$ residue would induce a conformational change in the enzyme that, in turn, would cause the previously cis-amide linkage to adopt a configuration intermediate between cis and trans and to thus lose all double-bond character. Subsequently, cleavage of the C-terminal dipeptide bond would occur with the help of catalytic groups of the active site thus formed in the enzyme. The conformational change in the enzyme together with the interactions between enzyme groups and substrate would have to supply an energy of about $30-40 \mathrm{~kJ} / \mathrm{mol}$ (energy barrier between cis and trans configurations). According to this model, distortion of the amide bond only occurs after the substrate is bound to the enzyme and as a consequence of the binding. Conversely, the change in the enzyme only occurs in the presence of bound substrate.

\section{The Exocellular R61 Enzyme as a Model for Transfer Reaction}

In transpeptidation reactions ( $\mathrm{Ac}_{2}$-L-Lys-D-Ala-D-Ala + acceptor $\rightarrow \mathrm{D}-\mathrm{Ala}+$ $\mathrm{Ac}_{2}$-L-Lys-D-Ala-acceptor) that occur in competition with the unavoidable hydrolysis of the tripeptide donor $\left(\mathrm{Ac}_{2}-\mathrm{L}-\mathrm{Lys}-\mathrm{D}-\mathrm{Ala}-\mathrm{D}-\mathrm{Ala}+\mathrm{H}_{2} \mathrm{O} \rightarrow \mathrm{Ac} \mathrm{c}_{2}\right.$-L-Lys$\mathrm{D}-\mathrm{Ala}+\mathrm{D}$-Ala), the enzyme utilized, with varying efficiency, a wide range of compounds (TABLES $2 \& 5$ ), such as glycine, D-amino acids (but not $\mathrm{L}$-amino acids), peptides with $\mathrm{N}$-terminal glycine or D-alanine, $\omega$-amino acids, aminohexuronic acids, 6-aminopenicillanic acid, and D-cycloserine. ${ }^{25}$

TABLE 2 shows that of the dipeptides that function as acceptors the most effective were those with $\mathrm{N}$-terminal glycine. This sequence resembles that found in the cross-links of corresponding peptidoglycan. With the most effective acceptor, glycyl-L-alanine, at an acceptor:donor ratio of $1: 1,25 \%$ of the donor 
was converted to transpeptidation product. Replacement of the glycine residue by L-alanine prevented acceptor function. Certain substances that were not glycyl peptides and had amino groups that were not at D-asymmetric centers were, however, able to function as acceptors (TABLE 5). For instance, $\omega$-amino acids were recognized by the enzyme; the shortest $\left(C_{3}\right)$ and longest $\left(C_{6}\right)$ examples studied were more effective than the intermediate chain lengths. Simple amines were not tested as acceptors, but glucosamine did not function. The spacing between the amino group and the carboxyl group was certainly not the only factor in determining the effectiveness of an acceptor, because, apart from the fact that $\mathrm{L}$ symmetry at the amino terminal prevented action, glycylglycine was a much better acceptor than 5 -aminovaleric acid, which has about the same separation between the free carboxyl and amino groups.

Compounds that were not simple peptides or amino acids also functioned as acceptors. Among these were the lactams of meso or racemic diaminoadipic acids, which in a sense are fixed-conformation analogs of D-alanyl-L-alanine and of D-alanyl-D-alanine, respectively (on the reasonable assumption that molecules with the amino function at the $\mathrm{L}$ asymmetric center were in neither case acceptors). ${ }^{25}$ The conformation of the diaminoadipic acid lactam is not known, but representations of possible conformers deduced from relatively strainless arrangements of atomic models are shown in FIGURE 5. The diametrical arrange-
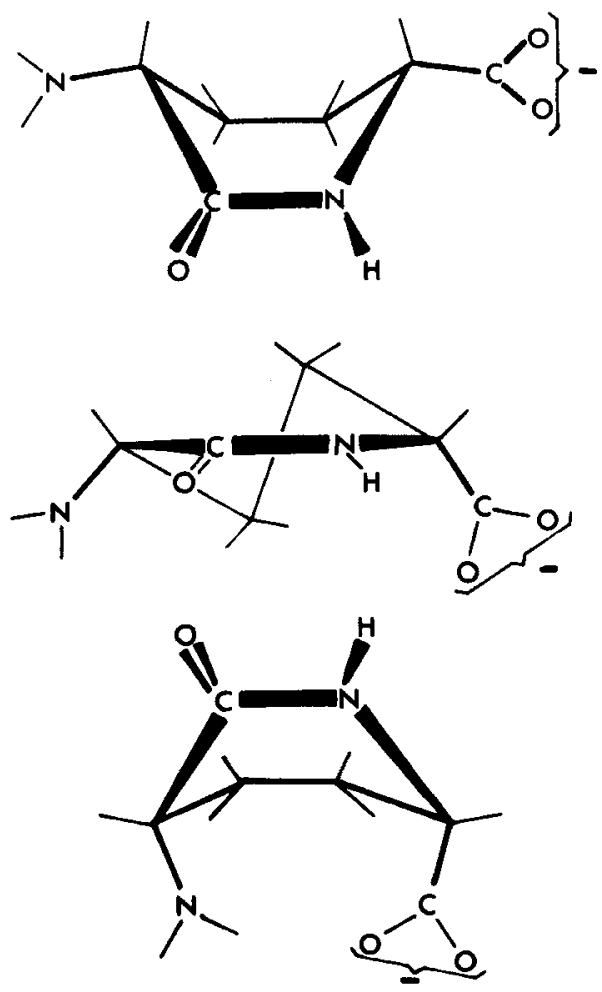

Figure 5. D,D-Diaminoadipic acid lactam. 


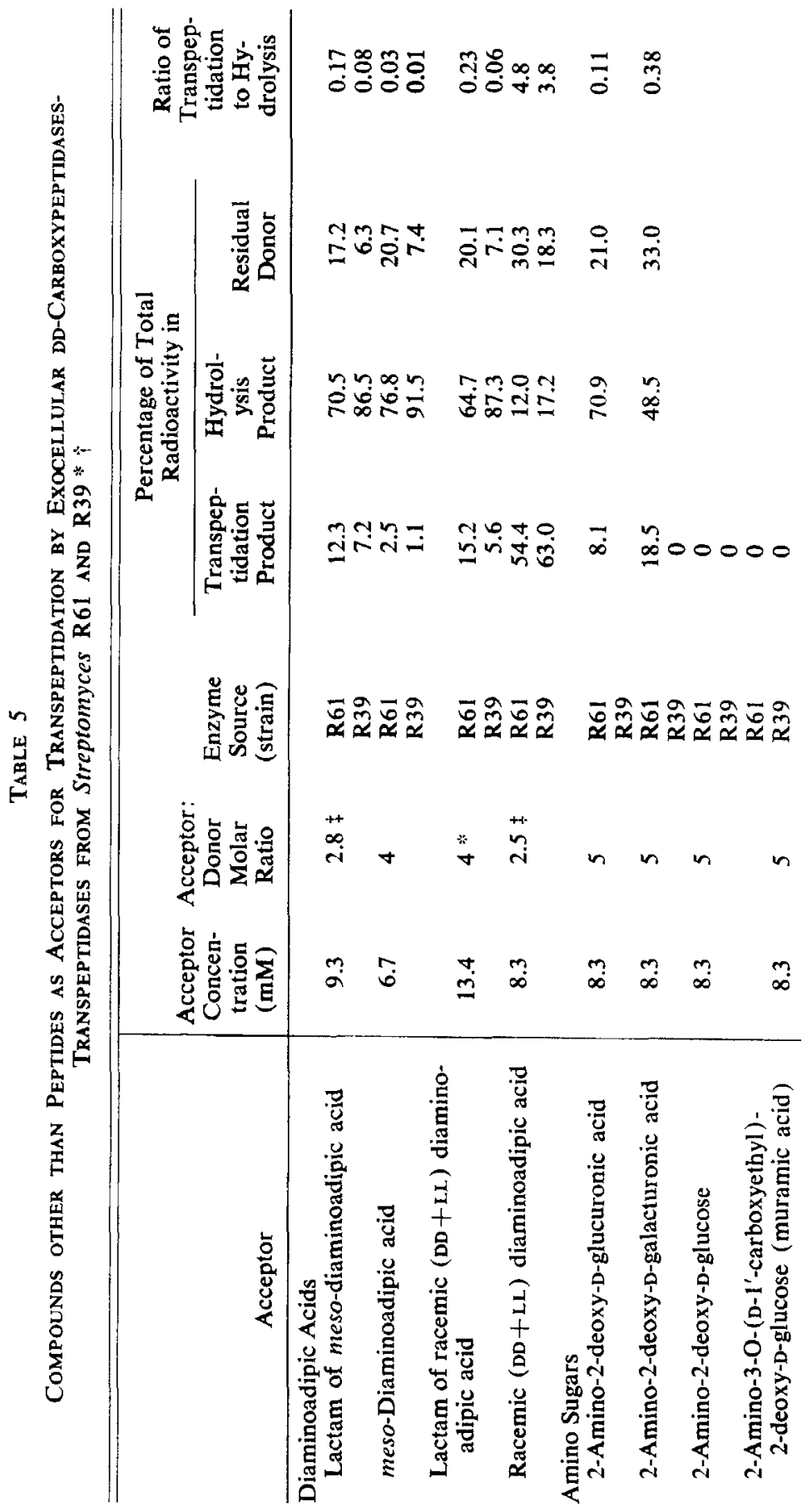




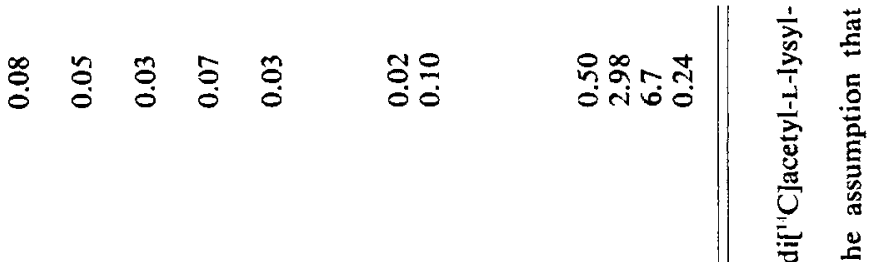

ザ

总

ن

产高

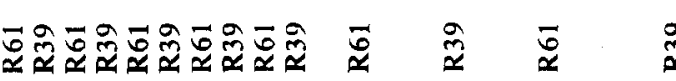

定

育站

2

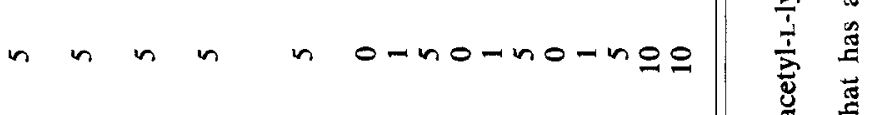

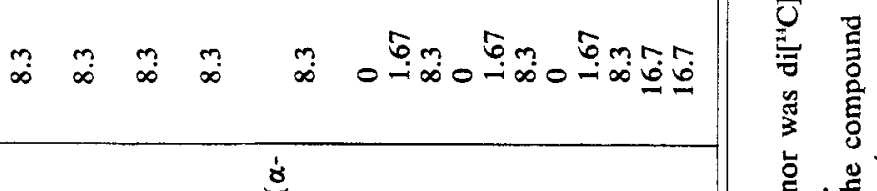

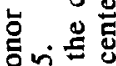

约

象影

원

때응

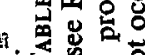

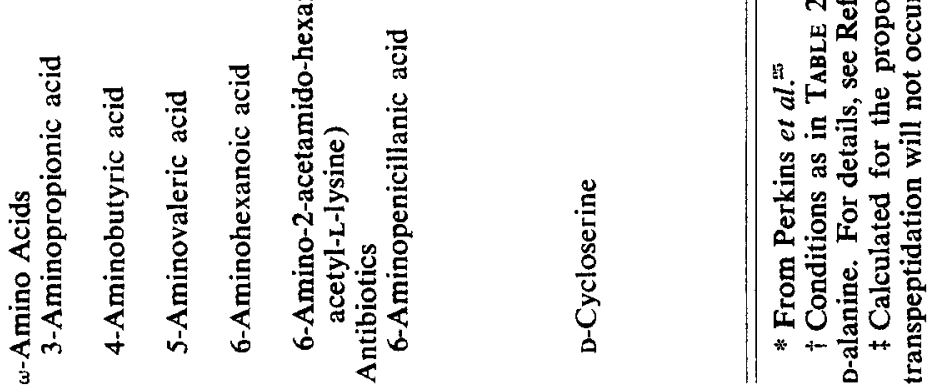


ment of the carboxyl and amino groups around a six-membered ring at once suggested an analogy with aminohexuronic acids. Again, the actual conformation of these compounds has not been determined, but Figure 6 shows Dglucosaminuronic acid in the $C_{1}$ conformation of Reeves, as found for salts of $\beta$-D-glucopyranuronic acid. ${ }^{36}$ The lower diagram gives the same conformation drawn to bring the amino and carboxyl groups into positions comparable to those in Figure 5. In fact, glucosaminuronic acid and galactosaminuronic acid were both good acceptors for transpeptidation by the soluble enzyme from strain R61 (TABLE 5). Ultimately, these observations must fit into any definition of the acceptor site for this enzyme.
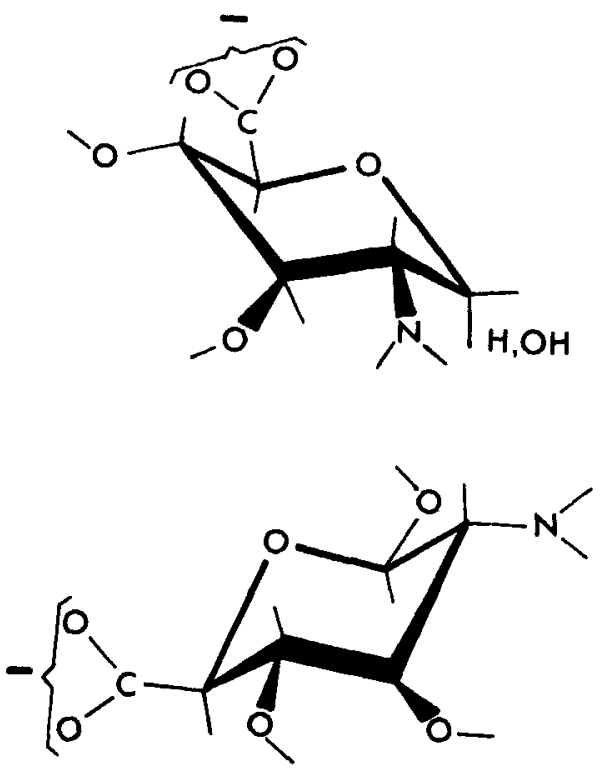

FIGURE 6. D-Glucosaminuronic acid.

Another molecule of fixed conformation with amino and carboxyl groups separated by about the same distance is 6-aminopenicillanic acid, and this too functioned as a rather poor acceptor. Evidently, this antibiotic could occupy the acceptor site on the R61 enzyme; but, of course, the penicillins are acylated at the 6-position, and it is most unlikely, therefore, that they could occupy a similar position on the enzyme.

The function of $\mathbf{D}$-cycloserine as an acceptor is of considerable interest. Presumably, it functions, as in its other activities, as an analog of D-alanine, which is itself an excellent acceptor (TABLE 2). If, indeed, D-cycloserine can also serve as an acceptor for transpeptidation in vivo, this may represent an additional facet of its mode of action. 


\section{Action of Benzylpenicillin on the R6I Membrane-Bound Transpeptidase}

Fixation of 25 pmoles of $\left[{ }^{14} \mathrm{C}\right]$ benzylpenicillin per milligram of protein of isolated membrane (and removal of the unbound benzylpenicillin) completely suppressed the transpeptidase activity (see above). When the penicillin-treated membranes were resuspended at $37^{\circ} \mathrm{C}$ in $17 \mathrm{mM}$ phosphate buffer ( $\mathrm{pH} \mathrm{8.0)}$, however, release of the bound radioactivity occurred spontaneously and was virtually complete after $3 \mathrm{hr}$, after which the recovery of the transpeptidase activity was also complete. ${ }^{37}$ Hence, benzylpenicillin binds firmly but not irreversibly to the membranes. The type of binding between penicillin and the membrane site(s) is under current study.

\section{Kinetics of Inhibition of the Exocellular R61 Enzyme by Penicillin}

Inhibition of the exocellular R61 enzyme by benzylpenicillin was fully reversible by dialysis ${ }^{30}$ or by treatment with $\beta$-lactamase. ${ }^{37}$ Large concentrations of $\beta$-mercaptoethanol ${ }^{30}$ and iodoacetate ${ }^{3 i}$ neither impaired the enzyme activity nor prevented its inhibition by benzylpenicillin, which suggested that sulfhydryl groups were involved neither in catalytic activity nor in penicillin inhibition.

Kinetically, inhibition of carboxypeptidase activity ( $\mathrm{Ac}_{2}-\mathrm{L}-\mathrm{Lys}-\mathrm{D}-\mathrm{Ala}-\mathrm{D}-$ $\mathrm{Ala}+\mathrm{H}_{2} \mathrm{O} \rightarrow \mathrm{D}-\mathrm{Ala}+\mathrm{Ac}_{2}-\mathrm{L}-$-Lys-D-Ala) by penicillin was competitive. The $K_{i}$ values $\left(10^{-7} \mathrm{M}\right)$ were 0.75 for benzylpenicillin, ${ }^{16} 33$ for penicillin $\mathrm{V}$, and 100 for carbenicillin and cephalothin. ${ }^{3 \tau}$

Kinetically, inhibition of concomitant transfer and hydrolysis reactions ( $\mathrm{Ac}_{2}$-L-Lys-D-Ala-D-Ala + meso-diaminopimelic acid (meso-DAP) $+\mathrm{H}_{2} \mathrm{O} \rightarrow$ D$\mathrm{Ala}+\mathrm{Ac}_{2}$-L-Lys-D-Ala-meso-DAP $+\mathrm{Ac}_{2}-\mathrm{L}-\mathrm{Lys}-\mathrm{D}-\mathrm{Ala}$ ) by penicillin $\mathrm{V}$ was competitive with respect to the donor, both in the hydrolysis and in the transpeptidation pathways $\left(K_{i}=6 \times 10^{-i} \mathrm{M}\right)$, and was noncompetitive with respect to the acceptor in the transpeptidation pathway $\left(K_{i}=9 \times 10^{-\tau} \mathrm{M}\right) .^{37}$ It should be remembered that the acceptor is by itself a noncompetitive inhibitor of the hydrolysis reaction (see above). meso-Diaminopimelic acid (and not a peptide) was used in these assays to avoid inhibition of the transpeptidation by excess of acceptor.

\section{Conformational Change in the Exocellular R61 Enzyme upon Binding of Benzylpenicillin}

Two techniques, fluorescence and circular dichroism, proved especially useful to study directly the following interaction: enzyme + benzylpenicillin $K_{\text {f }}$

$\rightleftarrows$ [enzyme-benzylpenicillin]. ${ }^{30}$ The quenching of the fluorescence of the en$K_{\text {r. }}$

zyme (at $320 \mathrm{~nm}$ ) induced by binding of benzylpenicillin (FIGURE 7) was used to calculate the amount of enzyme-benzylpenicillin complex formed. One mole of benzylpenicillin was bound per 35-39,000 $\mathrm{g}$ of enzyme, with an association constant $K_{a}$ of $1.1 \times 10^{8}$ liter $\cdot \mathrm{mol}^{-1}\left(K_{a}=\right.$ reverse of the concentration of benzylpenicillin at which half of the maximum quenching of the fluorescence is produced). These results were in good agreement with both the molecular 


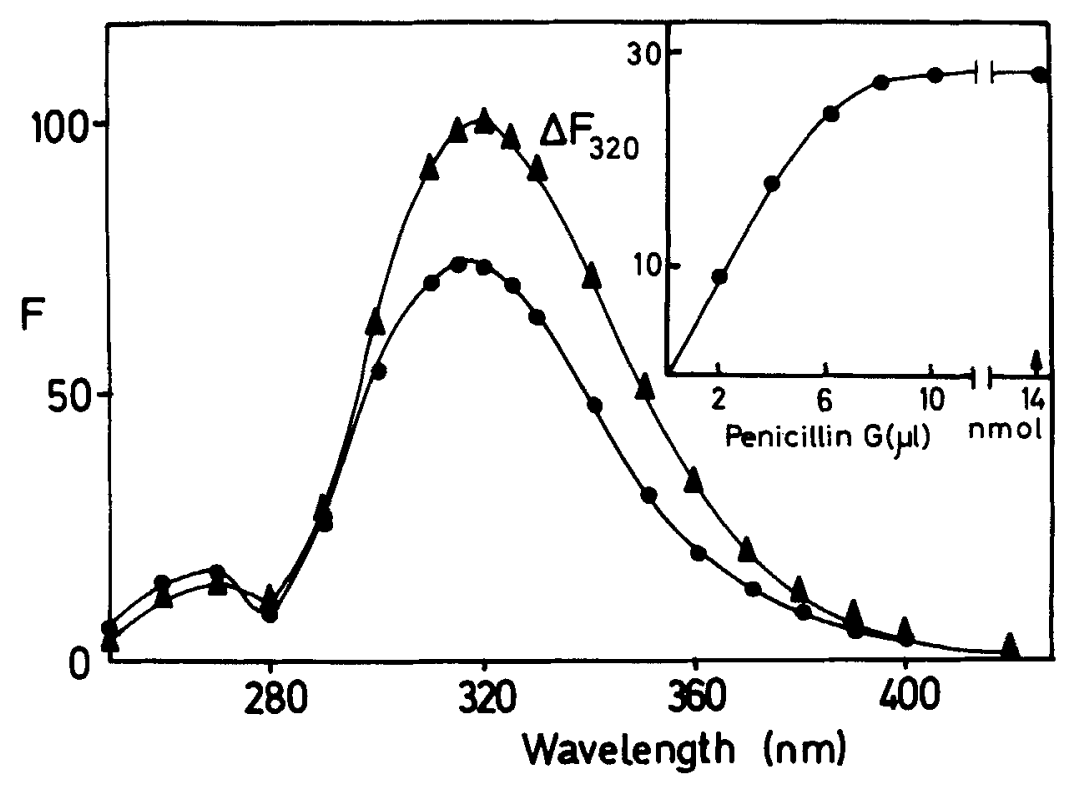

Figure 7. Emission spectrum of (A) R61 enzyme (95\% pure, $2 \mathrm{ml}$ of $26.5 \mu \mathrm{g}$ / $\mathrm{ml}$ ), and (-) the same enzyme solution saturated with benzylpenicillin. Excitation was at $273 \mathrm{~nm}$, and the experiment was performed at $25^{\circ} \mathrm{C}$ in $10 \mathrm{mM}$ sodium phosphate buffer $(\mathrm{pH} \mathrm{7.0)}$. Fluorescence intensity $(\mathrm{F})$ is expressed in arbitrary units; the maximum emission was considered as 100 . Insert: same experiment. Binding of benzylpenicillin to the enzyme as followed by fluorescence quenching at $320 \mathrm{~nm}$ $\left(\triangle F_{320}\right)$. The sodium benzylpenicillin solution $(0.232 \mathrm{mM})$ was in $10 \mathrm{mM}$ sodium phosphate buffer ( $\mathrm{pH} 7.0$ ). After $10 \mu$ lof this solution had been added, a large excess of benzylpenicillin $(5 \mu \mathrm{l}$ of $2.32 \mathrm{mM}$ ) was added to ensure saturation. (From Nieto et al. $^{20}$ By permission of The Biochemical Journal.)

weight obtained by analytical centrifugation and by polyacrylamide gel electrophoresis ${ }^{23}$ and the $K_{i}$ obtained kinetically ${ }^{16}$ and indicated that one mole of enzyme bound one mole of benzylpenicillin.

The combination between benzylpenicillin and the enzyme was relatively slow and reached equilibrium after about $10 \mathrm{~min}$ (FIGURE 8). In the first 3-4 min, when the forward reaction to the enzyme-benzylpenicillin complex was dominant, straight lines in second-order kinetic plots were obtained. The forward reaction rate constant $\left(K_{f}\right)$ so obtained was $1.1 \times 10^{4} \mathrm{liter} \cdot \mathrm{mol}^{-1} \cdot \mathrm{sec}^{-1}$, and the reverse rate constant $\left(K_{\mathrm{r}}=K_{\mathrm{f}} / K_{a}\right)$ was $1 \times 10^{-4} \cdot \mathrm{sec}^{-1}$ [in $0.01 \mathrm{mM}$ Tris-HCl buffer $(\mathrm{pH} 7.3)$ ]. Computer simulations of the kinetics of the reaction gave second-order plots that paralleled those obtained experimentally. ${ }^{38}$ In the absence of covalent bond formation (see above), this time dependence suggested that benzylpenicillin produced a conformational change in the enzyme with a Gibb's free energy change of approximately $45 \mathrm{~kJ} / \mathrm{mol}\left(\right.$ at $25^{\circ} \mathrm{C}$ ).

The near ultraviolet circular dichroism of the R61 enzyme was extensively affected by benzylpenicillin ${ }^{30}$ (FIGURE 9). According to the studies of Chen and Woody ${ }^{34}$ and of Hooker and Schellman, ${ }^{35}$ this property also indicated a 
conformational response of the enzyme. The conformational change was not very extensive, because it was not reflected in the far ultraviolet circular dichroism, which was unaltered in the presence of benzylpenicillin. The variations in the near ultraviolet circular dichroism were used in the same manner as the quenching of the fluorescence to construct titration plots, and they gave identical results. Fluorescence was preferred, however, because of its higher sensitivity.

Finally, an effect of benzylpenicillin on the conformation of the R61 enzyme was also indicated by its influence on the temperature of transition in the heat denaturation in $3.6 \mathrm{M}$ guanidine- $\mathrm{HCl}$. The antibiotic-saturated enzyme denaturated both faster and at a lower temperature $\left[f_{\mathrm{n}}=0.5\right.$ at $31^{\circ} \mathrm{C}\left(f_{\mathrm{n}}=\right.$ the fraction of protein in its native state) $]$ than the untreated protein $\left(f_{\mathrm{n}}=0.5\right.$ at $39^{\circ} \mathrm{C}$ ) (FIGURE 10).

\section{Influence of High Salt Concentrations and of Donor, Acceptor, and Inhibitor Peptides on Binding of Benzylpenicillin to the Exocellular R61 Enzyme}

High concentrations of salts (ammonium acetate, sodium phosphate, at $\mathrm{pH}$ 7.0) quenched the fluorescence of the R61 enzyme. $K_{a}$ values (at $25^{\circ} \mathrm{C}$ ) were 4 and 8 liter $\cdot \mathrm{mol}^{-1}$, and maximum quenching was 11 and $25 \%$, respectively. The quenching was very rapid, and no time dependence could be observed. The anion was probably responsible for the interaction, because the quenching was independent of the cation used. If the enzyme was first saturated with benzylpenicillin and then exposed to salts, the quenching produced by the latter and

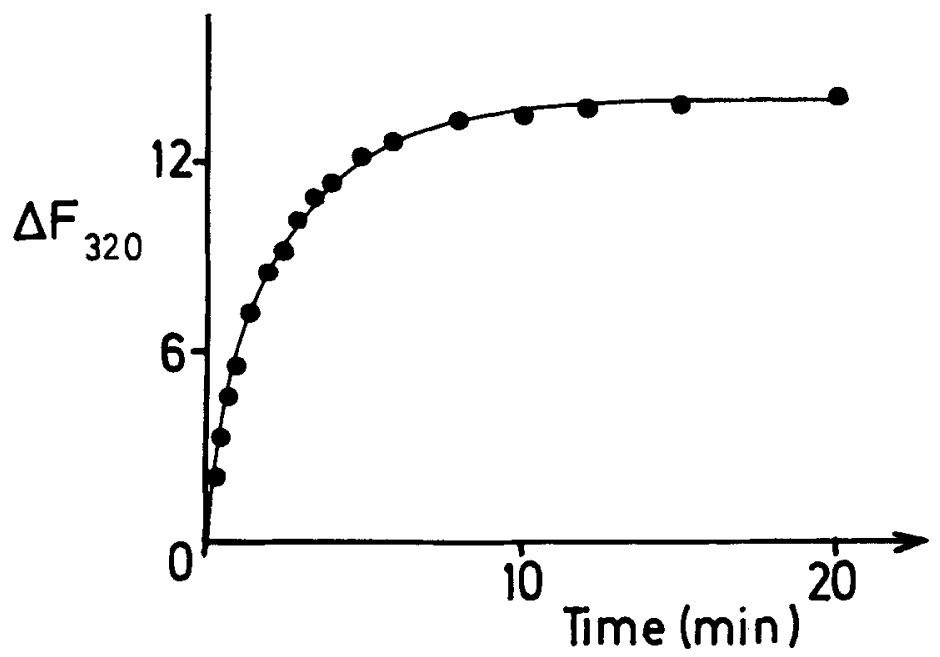

FIgure 8. Time course of the binding of sodium benzylpenicillin to the R61 enzyme. To a solution of the enzyme $\left(7.5 \times 10^{-7} \mathrm{M}\right)$ in $10 \mathrm{mM}$ sodium phosphate buffer ( $\mathrm{pH} 7.0$ ), antibiotic was added to a concentration of $7.6 \times 10^{-7} \mathrm{M}$, and the quenching of the fluorescence at $320 \mathrm{~nm}\left(\Delta F_{\text {923 }}\right)$ was followed with time. Other conditions were the same as in Figure 7. (From Nieto et $a l .^{30}$ By permission of The Biochemical Journal.) 


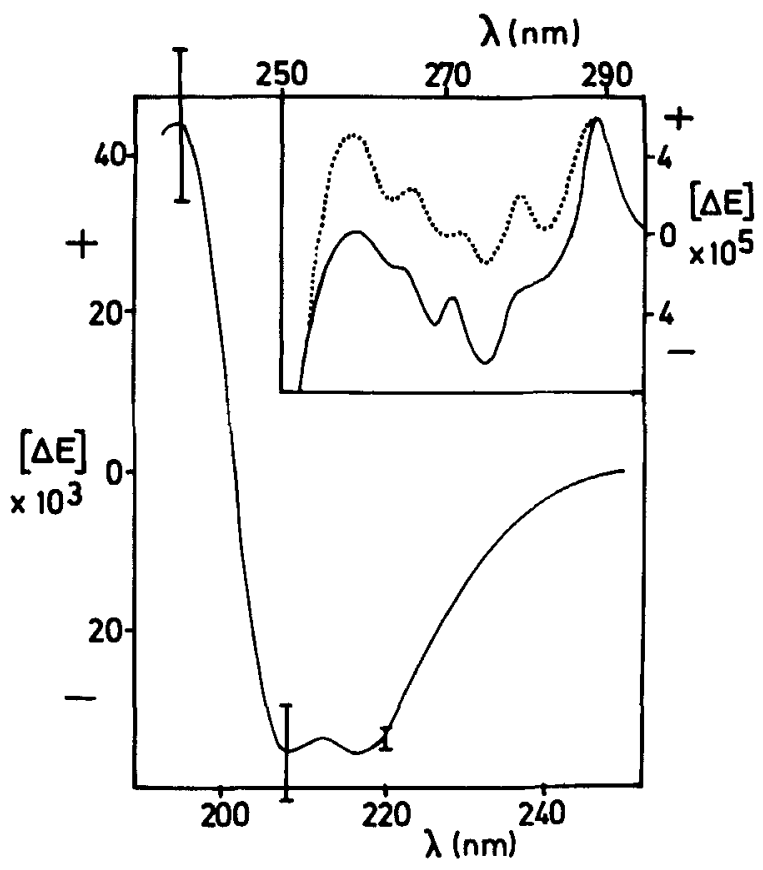

FIGURE 9. Near and far ultraviolet circular dichroism of the R61 enzyme alone $(-)$ and saturated with benzylpenicillin $(\cdot \cdot)$. Combination of the enzyme with benzylpenicillin did not alter the spectrum in the far ultraviolet, after correction for the dichroism of the antibiotic. $[\Delta E]$ is $\Delta E / c$, where $\Delta E$ is the measured value of the dichroism as the difference in absorption for left- and right-hand circularly polarized light in a light path of $1 \mathrm{~cm}$ and $c$ is the concentration of protein in $\mathrm{mg} / \mathrm{ml}$. Experiments were performed at $\mathrm{pH} 7.0$ and $21^{\circ} \mathrm{C}$. (From Nieto et al. ${ }^{30}$ By permission of The Biochemical Journal.)

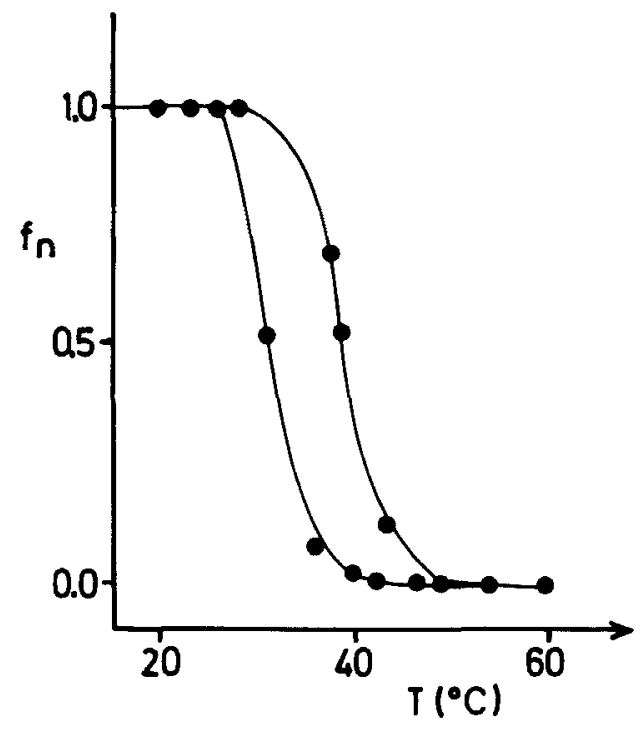

FIGURE 10. Influence of benzylpenicillin on the thermal transition of the enzyme in $3.6 \mathrm{M}$ guanidinium hydrochloride. The experiments were performed in $10 \mathrm{mM}$ phosphate buffer $\left(\mathrm{pH} \mathrm{7.0)} ; f_{\mathrm{n}}\right.$ is the fraction of enzyme in its native state. For explanations, see text. (From Nieto et al. ${ }^{80}$ By permission of The Biochemical Journal.) 
the apparent association were decreased (for ammonium acetate, $K_{n}$ became 1.3 liter $\cdot \mathrm{mol}^{-1}$, and maximum quenching was $\left.6-7 \%\right) .{ }^{30}$

The standard tripeptide donor, $N^{\alpha}, N^{\epsilon}$-diacetyl-L-lysyl-D-alanyl-D-alanine, and the hydrolysis product, $N^{\alpha}, N^{\epsilon}$-diacetyl-L-lysyl-D-alanine, were no better ligands than phosphate. Acceptors such as glycine or glycyl-L-alanine did not affect the fluorescence of the enzyme. ${ }^{30}$

The tripeptide donor and the dipeptide acetyl-D-alanyl-D-glutamic acid (a competitive inhibitor of the enzyme acting as carboxypeptidase; TABLE 4) at concentrations five times their $K_{m}$ and $K_{i}$ values, respectively, had very little effect on both the $K_{a}$ value and the rate constants $K_{\mathrm{f}}$ and $K_{r}$ of the interaction between the enzyme and benzylpenicillin. The same small effect was also observed with the hydrolysis product $N^{\alpha}, N^{\epsilon}$-diacetyl-L-lysyl-D-alanine, which was neither a substrate nor an inhibitor of the enzyme. The two acceptor molecules, glycine and glycyl-L-alanine, at concentrations that should saturate the acceptor site of the enzyme had no effect on either $K_{a}$ or the rate constants. ${ }^{30}$

Noticeable decreases of the $K_{a}$ and $K_{\mathrm{l}}$ values of the enzyme-benzylpenicillin interaction occurred in $0.19 \mathrm{M}$ sodium phosphate $\left(K_{a}=2.3 \times 10^{7} ; K_{\mathrm{f}}=\right.$ $\left.3.9 \times 10^{3}\right), 1 \mathrm{M}$ ammonium acetate $\left(K_{a}=2.6 \times 10^{5}\right)$, and $3.6 \mathrm{M}$ guanidine$\mathrm{HCl}\left(K_{a}=2.7 \times 10^{6} ; K_{\mathrm{f}}=1.3 \times 10^{2}\right)\left(\right.$ at $25^{\circ} \mathrm{C}$ and at neutral $\mathrm{pH}$ in all cases). The observed decreases of the $K_{a}$ values were mainly attributable to a slowing down of the forward reaction, whereas the $K_{\mathrm{r}}$ values changed relatively little. Hence, the affinity of the enzyme for benzylpenicillin was still very high under conditions where the enzyme was inactive (carboxypeptidase activity fell to $30 \%$ in $0.1 \mathrm{M}$ buffer ${ }^{16}$ and was zero in $0.6-0.7 \mathrm{M}$ guanidine$\mathrm{HCl}) .{ }^{30}$

\section{Mechanism of Inhibition of the Exocellular R61 Enzyme by Benzylpenicillin}

Both kinetics of inhibition by benzylpenicillin and optical studies clearly demonstrated that benzylpenicillin and acceptor peptide bound at different sites on the enzyme. With regard to the peptide donor, the situation was less clear-cut. Kinetically, the inhibition was competitive, which suggested that ternary (enzyme-donor-benzylpenicillin) complexes did not form. Competitive kinetics do not, however, necessarily exclude an inhibitory mechanism other than a direct competition between substrate and inhibitor for the same site on the free enzyme. Saturating concentrations of donor substrate did not appreciably interfere with the binding of benzylpenicillin. The antibiotic bound to the enzyme under conditions where the latter was totally inactive (i.e., in the presence of guanidine- $\mathrm{HCl}$ ). Furthermore, the mode of binding of benzylpenicillin and donor to the enzyme was very different, as reflected in the time dependence. Thus, the most straightforward conclusion seemed that the sites for donor and benzylpenicillin were totally, or at least partially, different but not totally independent; that is, the binding of penicillin affected the donor binding site, although the reverse might not be true.

Whatever the exact relationship between donor and benzylpenicillin binding sites, the mode of action of benzylpenicillin rested upon the demonstration that it produced a conformational change in the enzyme with liberation of a Gibb's free energy of about $45 \mathrm{~kJ} / \mathrm{mol}$ (at $25^{\circ} \mathrm{C}$ ). If ternary (enzyme-donor-benzylpenicillin) complexes are not formed, the penicillin-treated enzyme, in order to become again enzymatically active, would have to return to its normal confor- 
mation; that is, it would have to overcome an energy barrier of $45 \mathrm{~kJ} / \mathrm{mol}$ without any external supply of energy, which the enzyme is obviously unable to do. On the contrary, if (enzyme-donor-benzylpenicillin) complexes are allowed to form, there would be some external release of energy (through the binding of the donor peptide). However, the energy barrier between the conformation of the benzylpenicillin-saturated enzyme and that of the enzymatically productive complex in its activated state would then be $45+35 \mathrm{~kJ} / \mathrm{mol}$ (the $35 \mathrm{~kJ}$ represents the energy barrier between cis and trans configurations of the $\mathrm{C}$ terminal amide bond that is to be cleaved; see above). This $80 \mathrm{~kJ} / \mathrm{mol}$ energy barrier would be more than twice that required when the antibiotic is not present, and, presumably, the enzyme would again be unable to overcome it. Irrespective of the case, benzylpenicillin would, therefore, inhibit the enzyme, because it freezes it in a conformation that prevents activity.

\section{THE DD-CaRboxypeptidase-TRanspeptidase System IN Streptomyces STRAIN R39}

\section{Structure of the Wall Peptidoglycan}

In Streptomyces R39, the wall peptidoglycan is composed of L-alanyl-Disoglutaminyl-(L)-meso-diaminopimelyl-(L)-D-alanine tetrapeptides that are directly interlinked through $\mathrm{C}$-terminal $\mathrm{D}$-alanyl-(D)-meso-diaminopimelic acid linkages. ${ }^{19}$ The same structure was found in many gram-negative bacteria (except that the $\alpha$-carboxyl group of D-glutamic acid was not amidated) and in many bacilli. ${ }^{20}$ Because of this structure, the transpeptidation reaction in Streptomyces R39 must occur as shown in FIGURE 1. Note that the interpeptide bond made by transpeptidation is in an $\alpha$-position to a free carboxyl group.

\section{The Exocellular R39 Transpeptidase-DD-Carboxypeptidase}

The exocellular R39 enzyme consists of a single polypeptide chain. Its molecular weight is about 55,000. Turnover number with regard to its carboxypeptidase activity upon $N a, N{ }^{\epsilon}$-diacetyl-L-lysyl-D-alanyl-D-alanine was $850 . .^{37}$ The transpeptidase activity of the R39 enzyme relative to its carboxypeptidase activity was also enhanced by raising the $\mathrm{pH}$, by increasing the concentration of acceptor (within certain limits), and by decreasing the water content of the reaction mixtures. ${ }^{19}$ High concentrations in $\mathrm{K}_{.2} \mathrm{HPO}_{1}$, however, that suppressed the activity of the R61 enzyme, considerably favored the transpeptidase activity of the R39 enzyme. For this reason, most of the transpeptidation reactions with this enzyme were performed in $0.5 \mathrm{M} \mathrm{K}_{2} \mathrm{HPO}_{\downarrow}$ (ionic strength 1.5). ${ }^{19}$

Penicillins and cephalosporins inhibited the transpeptidase activity of the R39 enzyme at those concentrations that inhibited its carboxypeptidase activity ${ }^{21}$ (TABLE 1). Its susceptibility toward most of the $\beta$-lactam antibiotics was higher than that of the exocellular R61 enzyme. A similar difference was observed between the $L D_{, 0,}$ values for the two corresponding strains (TABLE 1). Kinetics of inhibition of the enzymic activities of the R39 enzyme by penicillin appeared to be a much more complex phenomenon ${ }^{17}$ than the inhibition of the R61 enzyme, and they are currently being studied. 


\section{Specificity Profle of Exocellular R39 Enzyme for Carboxypeptidase Activity}

The R39 enzyme, similar to the R61 enzyme, exhibited a considerable specificity for a C-terminal $L-R_{3}-D-A l a-D(O H)$ sequence and for a long aliphatic side chain at the $L-R_{3}$ residue. ${ }^{17,28}$ The occurrence of ionized groups at the end of this side chain, however, differently influenced the activity of the two enzymes (TABLE 3). The $K_{m}$ values of the R39 enzyme varied from $10 \mu \mathrm{M}$ for the best substrate so far studied (the pentapeptide L-Ala- $\gamma$-D-Glu-(L)-mesoDAP-(L)-D-Ala-D-Ala, vide infra) to $2.5 \mathrm{mM}$ for poor substrates. The $K_{m}$ value for the standard substrate $\mathrm{Ac}_{2}-\mathrm{L}-\mathrm{Lys}-\mathrm{D}-\mathrm{Ala}-\mathrm{D}-\mathrm{Ala}$ was $0.8 \mathrm{mM}$. The $V_{\max }$ values were relatively little affected by the substrates. None of the peptides that were inhibitory for the R61 enzyme (TABLE 4) had any effect on the carboxypeptidase activity of the R39 enzyme. ${ }^{29}$ In fact, some of them were good substrates for this enzyme.

\section{Specificity Profile of Exocellular R39 Enzyme for Transpeptidase Activity}

The most striking peculiarity of the R39 enzyme was its inability to catalyze transpeptidation reactions when $\omega$-amino acids, peptides, and 6-aminopenicillanic acid, instead of glycine or $\alpha$-D-amino acids, were tested as possible acceptors ${ }^{24,} \mathbf{2 5}$ (TABles $2 \& 5$ ). Clearly, this enzyme was unable to synthesize peptide bonds in an endo position. In fact, this peculiarity correlates very well with an important structural feature of the wall peptidoglycan of Streptomyces R39: the interpeptide bond made by transpeptidation is at a C-terminal position ${ }^{19}$ (FIgURE 1). The only effective acceptor for the R39 enzyme so far studied that had no free carboxyl group was D-cycloserine. ${ }^{25}$ This antibiotic, however, behaves as a zwitterion, with $\mathrm{p} K$ values of 4.4 and 7.4. At alkaline $\mathrm{pH}$, the charge properties would be similar to those of an $\alpha$-amino acid, and function as an acceptor could be rationalized. The basic requirement of the R39 enzyme for acceptor was, therefore, an amino group located on a $\mathrm{D}$ center in $\alpha$-position to a free carboxyl group. The influence exerted by the side chain was then studied with the help of peptides that were either similar or identical to the natural peptide L-alanyl- $\gamma$-D-isoglutaminyl-(L)-meso-diaminopimelyl-(L)-D-alanine (TABLE 6).

\section{Kinetics of Concomitant Transfer and Hydrolysis Reactions Catalyzed by the Exocellular R39 Enzyme}

The amide-free pentapeptide L-alanyl- $\gamma$-D-glutamyl-(L)-meso-diaminopimelyl-(L)-D-alanyl-D-alanine (peptide 1 in TABLE 6) was a substrate for the R39 enzyme, but its fate depended upon its concentration in the reaction mixture (FIGURE 11). $K_{m}$ values were approximately $10 \mu \mathrm{M}$ for hydrolysis and $10 \mathrm{mM}$ for transpeptidation, respectively. At concentrations lower than $200 \mu \mathrm{M}$, therefore, only hydrolysis into tetrapeptide occurred, whereas at higher concentrations, dimerization through the formation of a C-terminal D-alanyl-(D)-mesodiaminopimelic acid interpeptide bond (FIGURE 1) progressively increased in yield and hydrolysis was inhibited. ${ }^{37}$ 


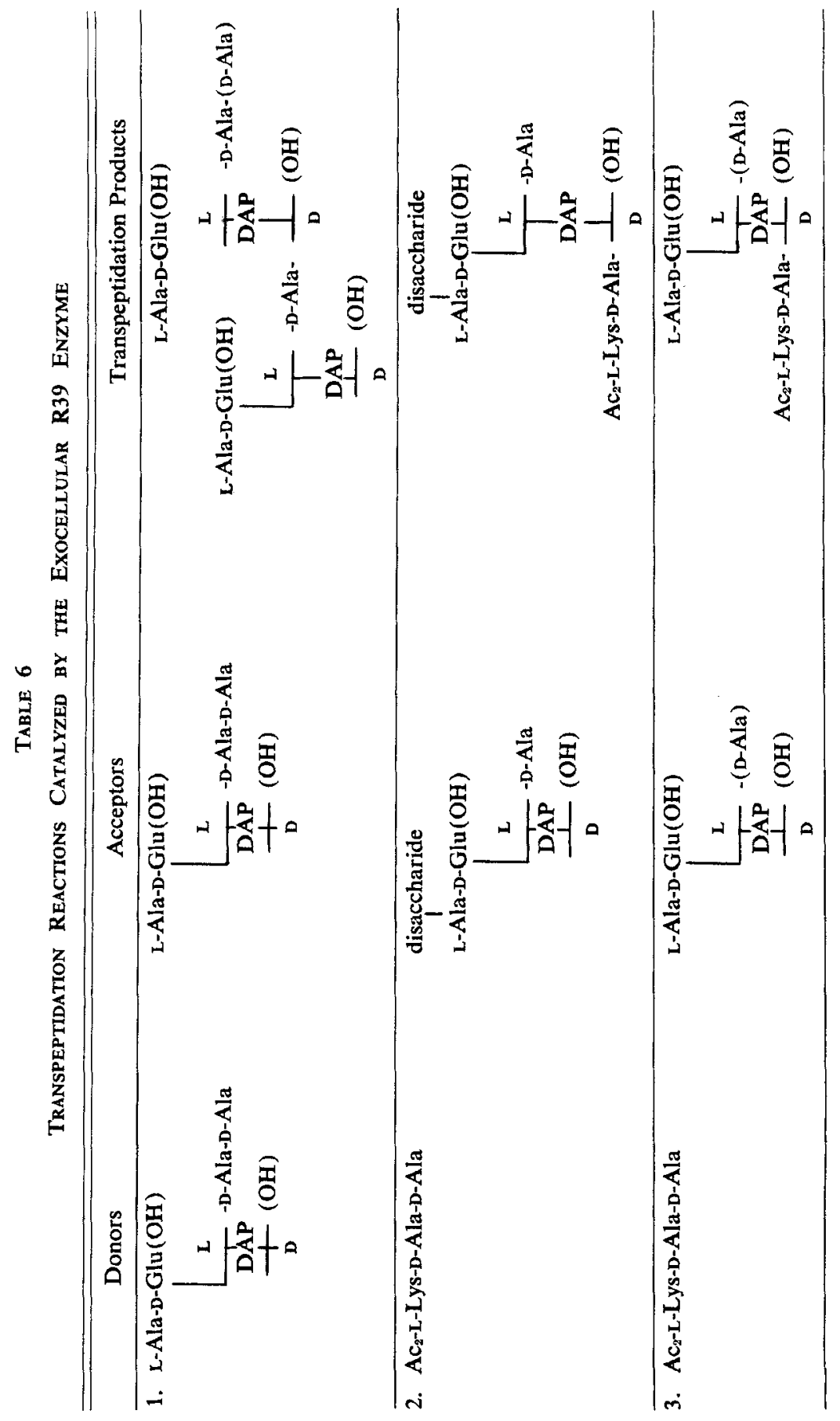


Ghuysen et al:: Streptomyces Penicillin Receptor

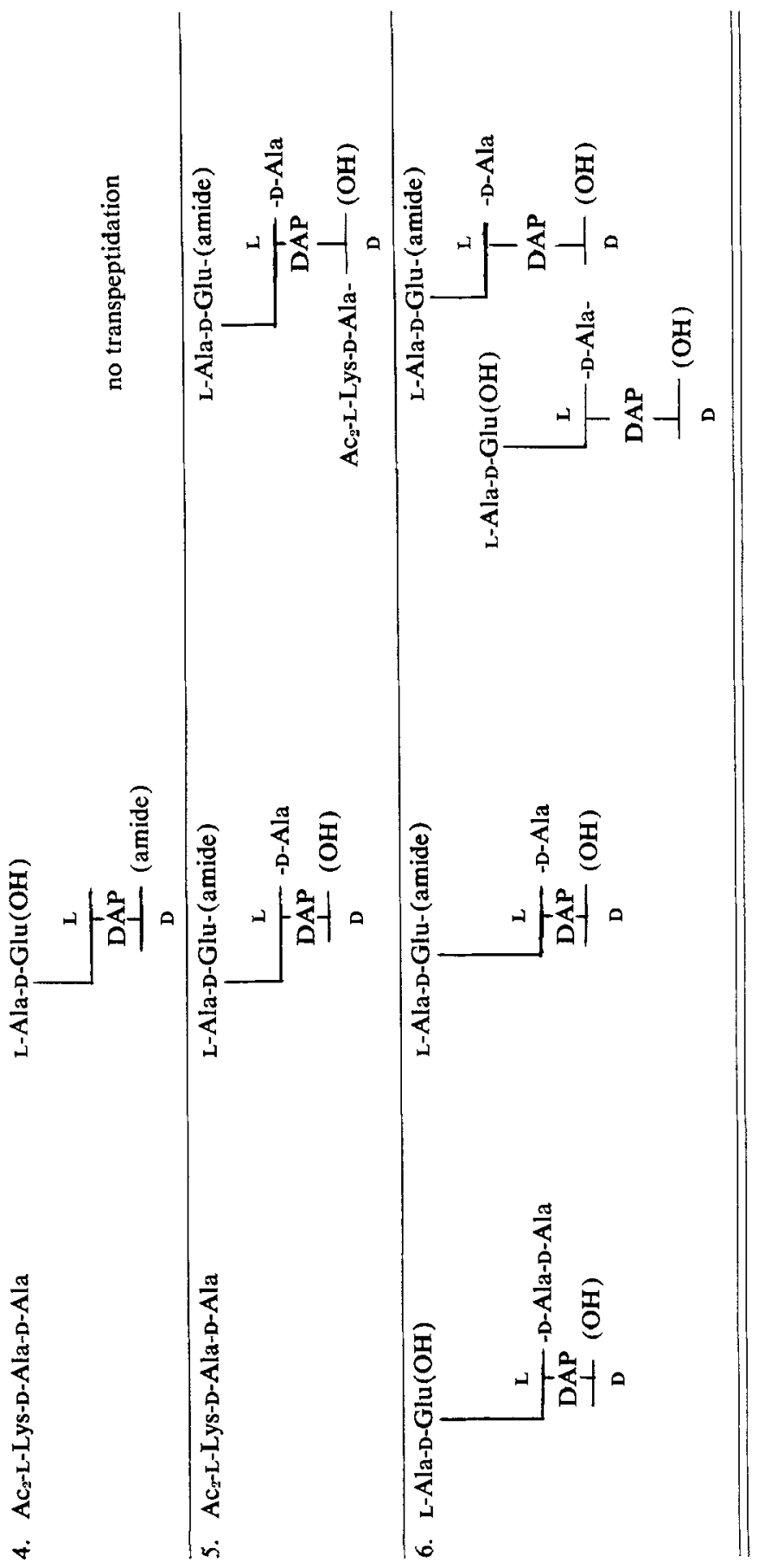




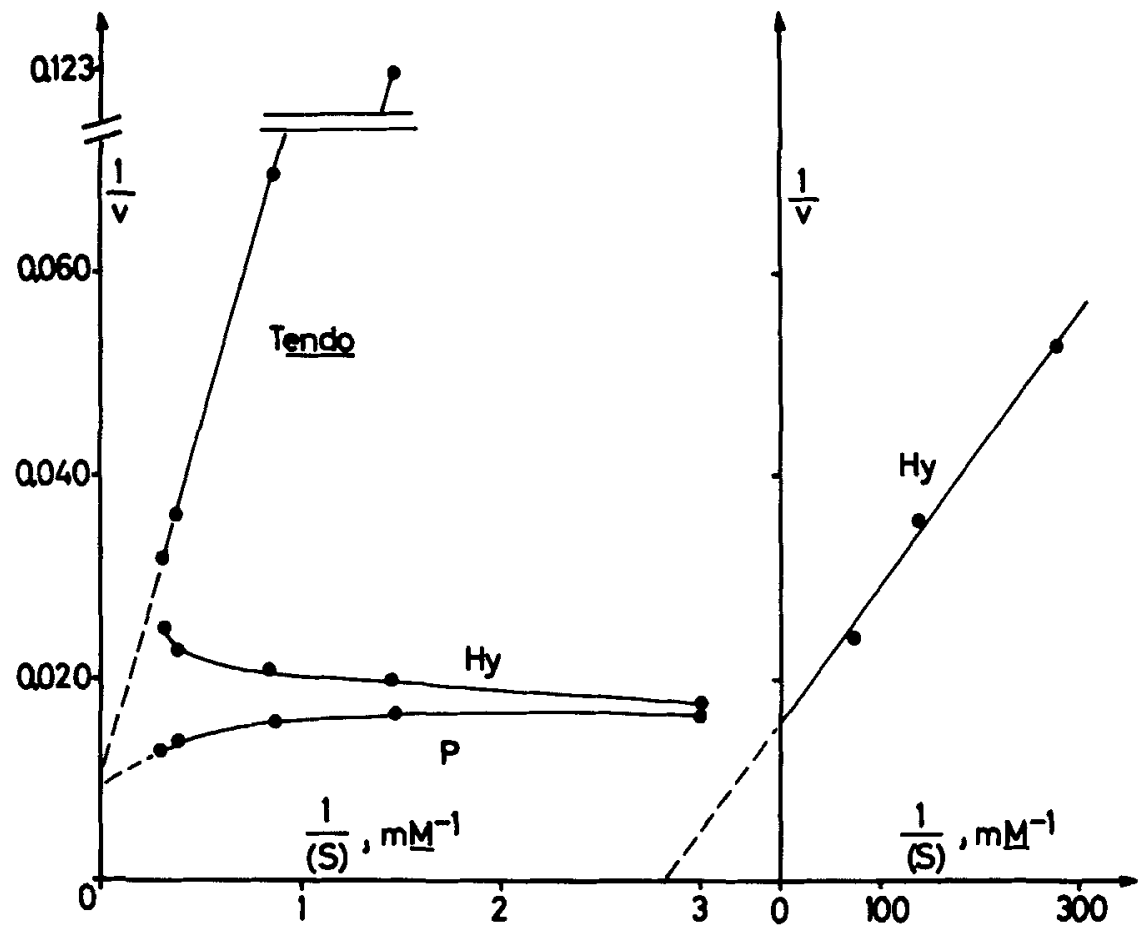

FIGURE 11. Transfer and hydrolysis reactions catalyzed by the exocellular R39 enzyme when acting on the pentapeptide $\mathrm{L}$-alanyl- $\gamma$-D-glutamyl-( $\mathrm{L})$-meso-diaminopimelyl-(L)-D-alanyl-D-alanine. Right: pentapeptide $(1.8 \mu \mathrm{M}-15 \mu \mathrm{M})$ was incubated at $37^{\circ} \mathrm{C}$ for $1 \mathrm{~min}$ in $15 \mu \mathrm{l}$ (final volume) of $0.5 \mathrm{M} \mathrm{K}_{2} \mathrm{HPO}_{4}$ in the presence of 3 units of R39 enzyme. Left: pentapeptide $(300-3400 \mu \mathrm{M})$ was incubated at $37^{\circ} \mathrm{C}$ for $30 \mathrm{~min}$ in $15 \mu \mathrm{l}$ (final volume) of $0.5 \mathrm{M} \mathrm{K}_{2} \mathrm{HPO}_{4}$ in the presence of 3 units of $\mathrm{R} 39$ enzyme. $\mathrm{Hy}$, hydrolysis of the pentapeptide into tetrapeptide and free D-alanine; Tendo, "endogenous" transpeptidation leading to dimerization (see system 1 in TABLE 6); $P$, total reaction (transpeptidation + hydrolysis) estimated by measuring the release of free D-Ala, which is the product common to both reactions. Rates of the reactions $(v)$ were expressed in pmoles of products formed per minute. Radioactive pentapeptide (D- $\left[{ }^{14} \mathrm{C}\right]$ Ala $\left.-\mathrm{D}-\left[{ }^{14} \mathrm{C}\right] \mathrm{Ala}\right)$ was used. It was a gift of Dr. P. Reynolds, Cambridge, England. 
The question of whether the occurrence of an amide group on the $\alpha$ carboxyl group of D-glutamic acid in the natural peptide was important for the transpeptidation reaction was investigated by studying the transfer of $N^{\alpha}, N^{\epsilon-}$ diacetyl-L-lysyl-D-alanyl from $N^{\alpha}, N^{\epsilon}$-diacetyl-L-lysyl-D-alanyl-D-alanine to the (D) amino group of meso-diaminopimelic acid in the following peptides: the nonamidated disaccharide tetrapeptide $\beta-1,4-G l c N A c-M u r N A C-L-a l a n y l-\gamma-D-$ glutamyl-(L)-meso-diaminopimelyl-(L)-D-alanine, the corresponding disaccharide-free tetrapeptide, the tripeptide $\mathrm{L}$-alanyl- $\gamma$-D-glutamyl-(L)-meso-diaminopimelic acid, the amidated tripeptide L-alanyl- $\gamma$-D-glutamyl-(L)-meso-diaminopimelic acid-(D)-amide, and the amidated tetrapeptide L-alanyl-D-isoglutaminyl(L)-meso-diaminopimelyl-(L)-D-alanine ${ }^{19}$ (peptides 2-4 in TABLE 6). With the three nonamidated acceptors, the yield of transpeptidation, at a given concentration of donor, was maximal at about the same concentration of acceptor. At this concentration of acceptor, the hydrolysis of the tripeptide donor, when compared to that which occurred in the absence of acceptor, was decreased to an extent greater than could be accounted for by transpeptidation. A further increase in acceptor concentration caused additional inhibition of the hydrolysis but did not affect the transpeptidation reaction. The effect of amidation of the carboxyl group on the D carbon of meso-diaminopimelic acid was drastic, in that it completely prevented the peptide from being recognized by the enzyme. This DAP-amidated peptide was not a substrate for transpeptidation and did not inhibit the hydrolysis of the tripeptide donor. The effect of amidation of the $\alpha$-carboxyl group of D-glutamic acid conferred on the acceptor a new property. At a given concentration of tripeptide donor, maximal tranispeptidation only occurred within a range of concentrations of acceptor. At higher concentrations of acceptor, both transpeptidation and hydrolysis reactions were progressively inhibited, until eventually they were completely abolished (FIGURE 12). This inhibition by excess acceptor (a property also exhibited by the R61 enzyme with some peptide acceptors) again pointed to the possible existence of control mechanisms that might be involved in the regulation of the activity of the enzyme in vivo. Other possible control mechanisms were also revealed by these studies. ${ }^{19}$ They included inhibition of transpeptidation by the transpeptidation product and hydrolysis of the transpeptidation product into intact peptide acceptor and dipeptide $N^{a}, N^{\epsilon}$-diacetyl-L-lysyl-D-alanine through the carboxypeptidase activity of the enzyme (hydrolysis of the C-terminal D-alanyl-(D)-meso-diaminopimelic acid made by transpeptidation).

Replacement of the tripeptide donor in the above system, Ac,-L-Lys-D-AlaD-Ala and Glu-amidated tetrapeptide, by the pentapeptide donor I-alanyl- $\gamma$ D-glutamyl-(L)-meso-diaminopimelyl-(L)-D-alanyl-D-alanine (at concentrations lower than $200 \mu \mathrm{M}$ to avoid "endogenous" transpeptidation; see above) gave rise to similar results with respect to kinetics of hydrolysis and of transpeptidation. The transpeptidation product, of course, was the dimer in which a Glu-amidated tetrapeptide and a nonamidated tetrapeptide were linked together, that is, a dimer that, if one excepts the lack of one amide group, was identical to that found in the completed wall peptidoglycan of Streptomyces R39. With both systems (Ac,-L-Lys-D-Ala-D-Ala + Glu-amidated tetrapeptide or nonamidated pentapeptide + Glu-amidated tetrapeptide), the influences exerted by the concentration of the donor $[D]$ and the concentration of the acceptor [A] on the ratios $v_{\mathrm{T}} / v_{\mathrm{II} y}$ suggested for the reactions an ordered mechanism in which the acceptor binds first and the occurrence on the enzyme of an additional inhibitory binding site for the Glu-amidated acceptor. ${ }^{37} \mathrm{~A}$ 


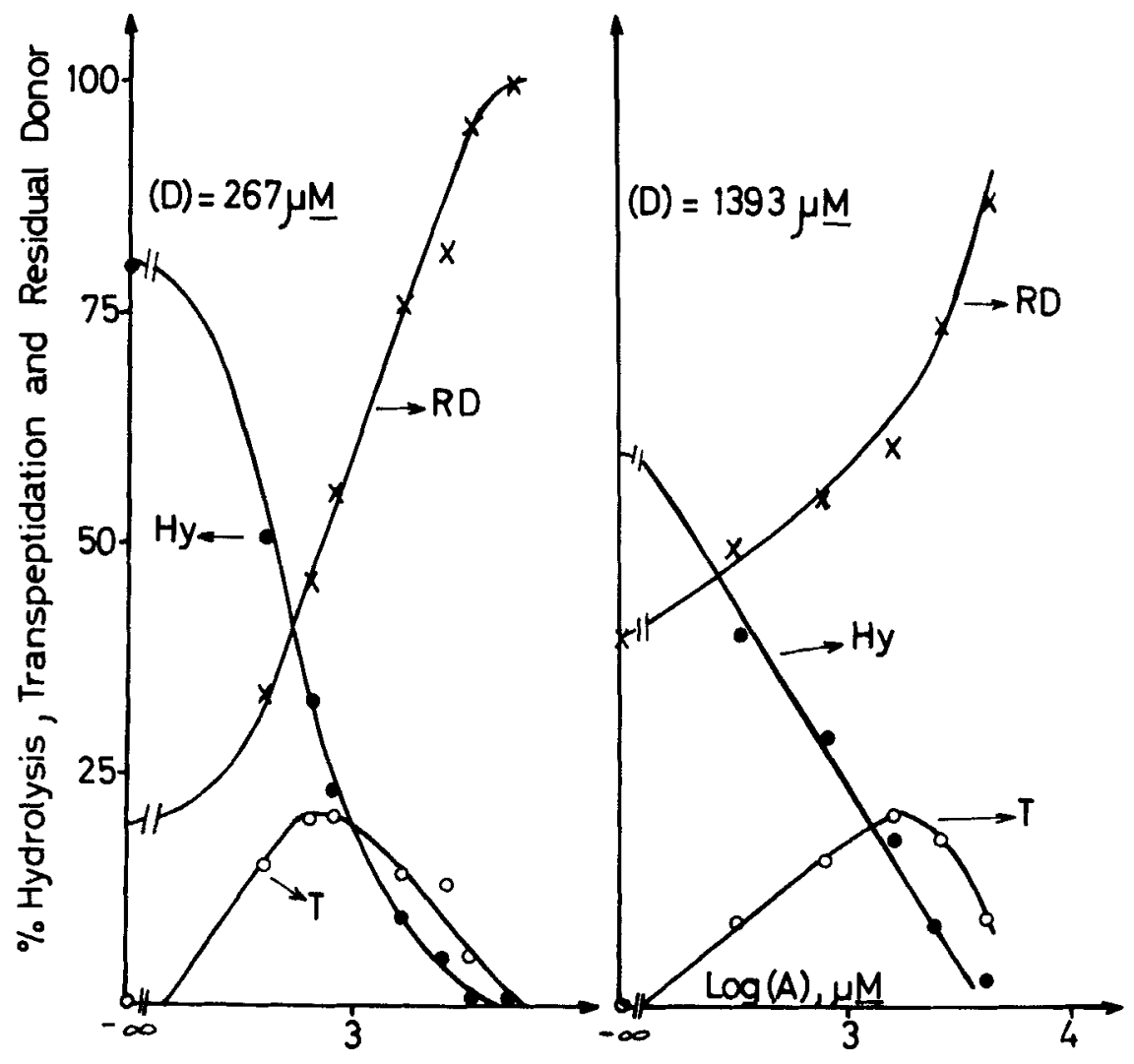

FIGURE 12. Concomitant transfer and hydrolysis reactions catalyzed by the exocellular R39 enzyme with the system tetrapeptide acceptor (L-alanyl-D-isoglutaminyl(L) -meso-diaminopimelyl-(L)-D-alanine) and tripeptide donor $N^{\alpha}, N^{\epsilon}$-diacetyl-L-lysylD-alanyl-D-alanine. Influence of concentration of acceptor at two concentrations of donor (267 and $1393 \mu \mathrm{M}$, respectively) on hydrolysis of the donor (Hy), transpeptidation (T), and residual donor (RD). Acceptor $(320-4800 \mu \mathrm{M}$ ) and donor (267 or $1393 \mu \mathrm{M}$ ) were incubated for $30 \mathrm{~min}$ at $37^{\circ} \mathrm{C}$ in $15 \mu 1$ (final volume) of $0.5 \mathrm{M}$ $\mathrm{K}_{2} \mathrm{HPO}_{4}$ in the presence of 34 units of R39 enzyme. Under these conditions, at optimal concentrations of acceptor (700 and $1600 \mu \mathrm{M}$, respectively), 30 and 150 pmole of donor are transformed into transpeptidation product per minute, which depends upon the concentration of donor used ( 267 and $1363 \mu \mathrm{M}$, respectively); that is, the rate of transpeptidation is proportional to the concentration of donor. 
similar situation had been found with the exocellular R61 enzyme when acting on the system Ac.-L-Lys-D-Ala-D-Ala + Gly-L-Ala (see above).

\section{The DD-Carboxypeptidase-Transpeptidase System IN Streptomyces StRains K11 AND albus G}

Insofar as could be judged, the exocellular enzyme from Streptomyces K11 exhibited properties very similar, if not identical, to those of the R61 enzyme with respect to both carboxypeptidase and transpeptidase activities ${ }^{17}, 24,25,29$ (TABLES 2 \& 3). Strains K11 and R61 had wall peptidoglycans of identical structure (FIGURE 1) but differed from each other in their ability to produce $\beta$-lactamase. ${ }^{21,} 22$

The exocellular DD-carboxypeptidase from $S$. albus $\mathrm{G}$ did not affect transpeptidation with any of the acceptors tried $2 \cdot, 2 \pi$ (TABLE 2). It was also exceptional in other respects: it was a cationic protein (even at $\mathrm{pH} 8$ ), lysed bacterial walls or cells in which the interpeptide bonds are C-terminal D-alanyl-D linkages, and was virtually not affected by penicillin. ${ }^{28,31-33}$ The carboxypeptidases from Streptomyces R61, K11, and R39 exerted endopeptidase activity (see above) on isolated peptide dimers and oligomers but were not bacteriolytic agents. It is possible that their anionic properties prevented them from combining with the bacterial walls and exerting a lytic activity. Possibly, the true transpeptidase of $S$. albus $\mathrm{G}$ is not the same as the isolated carboxypeptidase.

The $S$. albus G DD-carboxypeptidase, although not inhibited by penicillins and cephalosporins, was inhibited by peptide analogs ${ }^{29}$ of the standard substrate

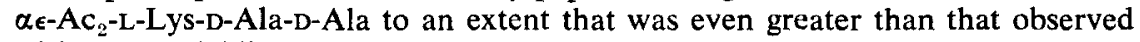
with the penicillin-sensitive R61 enzyme (TABle 4). Altogether, these observations and the fact that the R39 enzyme which exhibited the highest sensitivity to penicillin was not inhibited by these peptide analogs (see above) are another demonstration that binding sites for penicillin in sensitive enzymes are probably independent of the binding sites for the donor substrates.

\section{CONClusions}

Depending upon the bacterial species, the independence between the substrates and penicillin sites on the DD-carboxypeptidases-transpeptidases might be somewhat pronounced. Enzymes that have lost their acceptor and/or penicillin binding site(s) may exist. Enzymes may also exist in which binding of penicillin would not affect binding of the donor and even of the subsequent enzymatic catalysis. All would depend on whether the conformational change induced by penicillin involves peptide chains in the enzyme that need conformational freedom for normal catalysis. Activation of catalysis by penicillin can even be easily envisaged by assuming that the conformation induced in the protein by penicillin binding would result in a more favorable alignment of the catalytic groups. Penicilloylation of reactive side chains in some enzymes could be a secondary event and could occur after the conformation change has occurred, if, as a consequence of it, a susceptible side chain were placed in a spatially favorable position. Finally, the present proposal of the mode of action of penicillin also explains many facts unaccounted for where simple 
structural similarity between penicillin and transpeptidase substrates is invoked, ${ }^{1,2}$ such as the role of the acyl group of penicillins and the lack of recognition by penicillinases of DD-carboxypeptidase substrates. ${ }^{22,30}$

\section{SUMMARY}

Kinetics and optical studies of Streptomyces DD-carboxypeptidases-transpeptidases led to the conclusion that the donor, acceptor, and penicillin sites on these enzymes are different but not independent and that penicillin acts as a modifier of the conformation of the protein. In the presence of penicillin, the penicillin-sensitive enzymes would be frozen in a conformation that prevents catalytic activity.

\section{REFERENCES}

1. Wise, E. M., JR. \& J. T. PARK. 1965. Penicillin: its basic site of action as an inhibitor of a peptide crosslinking reaction in cell wall mucopeptide synthesis. Proc. Nat. Acad. Sci. USA 54: 75-81.

2. Tipper, D. J. \& J. L. Strominger. 1965. Mechanism of action of penicillins: a proposal based on their structural similarity to acyl-D-alanyl-D-alanine. Proc. Nat. Acad. Sci. USA 54: 1133-1141.

3. MaAs, E. A. \& M. J. Johnson. 1949. Penicillin uptake by bacterial cells. J. Bacteriol. 57: 415-422.

4. Rogers, H. J. 1967. The inhibition of mucopeptide synthesis by benzylpenicillin in relation to irreversible fixation of the antibiotic by staphylococci. Biochem. J. 103: $90-102$.

5. Edwards, J. R. \& J. T. Park. 1969. Correlation between growth inhibition and the binding of various penicillins and cephalosporins to Staphylococcus aureus. J. Bacteriol. 99: 459-462.

6. Park, J. M., M. E. Griffith \& I. Stevenson. 1971. Resistance to penicillin in mutants of a penicillinase-negative organism, Staphylococcus aureus H. J. Bacteriol. 108: 1154-1160.

7. Suginaka, H., P. M. Blumberg \& J. L. Strominger. 1972. Multiple penicillinbinding components in Bacillus subtilis, Bacillus cereus, Staphylococcus aureus and Escherichia coli. J. Biol. Chem. 247: 5279-5288.

8. Blumberg, P. M. \& J. L. Strominger. 1972. Isolation by covalent affinity chromatography of the penicillin-binding components from membranes of Bacillus subtilis. Proc. Nat. Acad. Sci. USA 69: 3751-3755.

9. Izaki, K., M. Matsuhashi \& J. L. Strominger. 1966. Glycopeptide transpeptidase and D-alanine carboxypeptidase:penicillin-sensitive enzymatic reactions. Proc. Nat. Acad. Sci. USA 55: 656-663.

10. Izaki, K., M. Matsuhashi \& J. L. Strominger. 1968. Biosynthesis of the peptidoglycan of bacterial cell walls. XIII. Peptidoglycan transpeptidase and D-alanine carboxypeptidase penicillin-sensitive enzymatic reaction in strains of Escherichia coli. J. Biol. Chem. 243: 3180-3192.

11. ARAkI, V., A. T. Shimada \& E. Ito. 1966. Effect of penicillin on cell wall mucopeptide synthesis in an Escherichia coli particulate system. Biochem. Biophys. Res. Commun. 23: 518-525.

12. Araki, V., R. Shirai, A. Shimada, N. Ishimoto \& E. Ito. 1966. Enzymatic synthesis of cell wall mucopeptide in a particulate preparation of Escherichia coli. Biochem. Biophys. Res. Commun. 23: 466-472.

13. Wickus, G. G. \& J. L. Strominger. 1972. Penicillin-sensitive transpeptidation during peptidoglycan biosynthesis in cell-free preparation from Bacillus 
megaterium. II. Effect of penicillin and cephalosporins on bacterial growth and in vitro transpeptidation. J. Biol. Chem. 247: 5307-5311.

14. Mirelman, D. \& N. Sharon. 1972. Biosynthesis of peptidoglycan by a cell wall preparation of Staphylococcus aureus and its inhibition by penicillin. Biochem. Biophys. Res. Commun. 46: 1909-1917.

15. Mirelman, D., R. Bracha \& N. Sharon. 1972. Role of the penicillin-sensitive transpeptidation reaction in attachment of newly synthesized peptidoglycan to cell walls of Micrococcus luteus. Proc. Nat. Acad. Sci. USA 69: 3355-3359.

16. Leyh-Bouille, M., J. Coyette, J. M. Ghuysen, J. Idczak, H. R. Perkins \& M. NIETo. 1971. Penicillin-sensitive DD-carboxypeptidase from Streptomyces strain R61. Biochemistry 10: 2163-2170.

17. Leyh-Boullle, M., M. Nakel, J. M. Frère, K. Johnson, J. M. Ghuysen, M. Nieto \& H. R. Perkins. 1972. Penicillin-sensitive DD-carboxypeptidase from Streptomyces strains R39 and K11. Biochemistry 11: 1290-1298.

18. Leyh-Boullle, M., R. Bonaly, J. M. Ghuysen, R. Tinelli \& D. J. Tipper. 1970. LL-diaminopimelic acid containing peptidoglycans in walls of Streptomyces sp and of Clostridium perfringens (type A). Biochemistry 9: 29442952.

19. Ghuysen, J. M., M. Leyh-Bouille, J. N. Campbeli, R. Moreno, J. M. Frère, C. Duez, M. Nieto \& H. R. Perkins. 1973. The structure of the wall peptidoglycan of Streptomyces R39 and the specificity profile of its exocellular DD-carboxypeptidase-transpeptidase for peptide acceptors. Biochemistry 12: $1243-1251$.

20. Ghuysen, J. M. 1968. Use of bacteriolytic enzymes in determination of wall structure and their role in cell metabolism. Bacteriol. Rev. 32: 425-464.

21. Dusart, J., A. Marquet, J. M. Ghuysen, J. M. Frère, R. Moreno, M. LeyhBouille, K. Johnson, Ch. Lucchi, H. R. Perkins \& M. Nieto. 1973. DD-carboxypeptidase-transpeptidase and killing site of $\beta$-lactam antibiotics in Streptomyces R39, R61 and K11. Antimicrob. Ag. Chemother. 3: 181-187.

22. Johnson, K., J. Dusart, J. N. Campbell. \& J. M. Ghuysen. 1973. The exocellular $\beta$-lactamases of Streptomyces strains R39, K11 and albus G. Antimicrob. Ag. Chemother. 3: 289-298.

23. Frère, J. M., J. M. Ghuysen, H. R. Perkins \& M. Nieto. 1973. Molecular weight and amino acid composition of the exocellular DD-carboxypeptidasetranspeptidase of Streptomyces R61. Biochem. J. 135: 463-468.

24. Pollock, J. J., J. M. Ghuysen, R. Linder, M. R. J. Salton, H. R. Perkins, M. Nieto, M. Leyh-Bouille, J. M. Frère \& K. Johnson. 1972. Transpeptidase activity of Streptomyces D-alanyl-D-carboxypeptidases. Proc. Nat. Acad. Sci. USA 69: 662-666.

25. Perkins, H. R., M. Nieto, J. M. Frère, M. Leyh-Bouille \& J. M. Ghuysen. 1973. Streptomyces DD-carboxypeptidases as transpeptidases. The specificity for amino campounds acting as carboxyl acceptors. Biochem. J. 131: 707-718.

26. Frère, J. M., J. M. Ghuysen, H. R. Perkins \& M. Nieto. 1973. Kinetics of concomitant transfer and hydrolysis reactions catalyzed by the exocellular DD-carboxypeptidase-transpeptidase of Streptomyces R61. Biochem. J. 135: 483-492.

27. Frère, J. M. 1973. Enzymic mechanisms involving concomitant transfer and hydrolysis reactions. Biochem. J. 135: 469-481.

28. Ghuysen, J. M., M. Leyh-Bouille, J. M. Frère, J. Dusart, K. Johnson, M. Nakei, I. Coyette, H. R. Perkins \& M. Nieto. 1972, Streptomyces DD-carboxypeptidases-transpeptidases and mechanism of action of penicillin. In Molecular Mechanisms of Antibiotic Action on Protein Biosynthesis and Membranes. E. Munoz, F. Garcia-Ferrandiz \& D. Vazquez, Eds. : 406-426. Elsevier Publ. Co. Amsterdam, The Netherlands.

29. Nieto, M., H. R. Perkins, M. Leyh-Boullle, J. M. Frère \& J. M. Ghuysen. 1973. Peptide inhibitors of Streptomyces DD-carboxypeptidases. Biochem. J. 131: $163-171$. 
30. Nieto, M., H. R. Perkins, J. M. Frère \& J. M. Ghuysen, 1973. Fluorescence and circular dichroism studies on the Streptomyces R61 DD-carboxypeptidasetranspeptidase. Penicillin binding by the enzyme. Biochem. J. 135: 493-505.

31. Ghuysen, J. M., M. Leyh-Bouille, R. Bonaly, M. Nieto, H. R. Perkins, K. H. SchleIfER \& O. KANDLER. 1970. Isolation of DD-carboxypeptidase from Streptomyces albus G culture filtrates. Biochemistry 9: 2955-2961.

32. Leyh-Boullle, M., J. M. Ghuysen, R. Bonaly, M. Nieto, H. R. Perkins, K. H. Schleifer \& O. Kandler. 1970. Substrate requirements of the Streptomyces albus G DD-carboxypeptidase. Biochemistry 9: 2961-2970.

33. Leyh-Bouille, M., J.-M. Ghuysen, M. Nieto, H. R. Perkins, K. H. Schleifer \& O. KANDLER. 1970. On the Streptomyces albus G DD-carboxypeptidase. Mechanism of action of penicillin, vancomycin and ristocetin. Biochemistry 9: 2971-2975.

34. CHEN, A. K. \& R. W. Woody. 1971. A theoretical study of the optical rotatory properties of poly-L-tyrosine. J. Amer. Chem. Soc. 93: 29-37.

35. Hooker, T. M. \& J. A. Schellman. 1970. Optical activity of aromatic chromophores. I. o-, m- and p-tyrosines. Biopolymers 9: 1319-1348.

36. Furberg, S., H. Hammer \& A. Mostad. 1963. The crystal structure of potassium glucuronate dehydrate. Acta Chem. Scand. 17: 2444-2454.

37. Ghuysen, J.-M., M. Leyh-Bouille, J. M. Frère, J. Dusart, A. Marquet, H. R. Perkins \& M. Nieto. Unpublished observations.

38. Flanagan, M. T. \& M. Nieto. Unpublished observations.

\section{Discussion}

Dr. J. L. Strominger: You and your collaborators have made an important contribution in providing an assay for transpeptidation with artificial substrates. We tried to assay this activity in the reverse direction by the formation of monomers from the cross-linked dimer. Endopeptidase catalyzes the hydrolysis of the dimer, and another possible assay for transpeptidation is the cleavage of the cross-bridge in the dimer by $D$-alanine, which is the reversal of transpeptidation. Because transpeptidation is a reaction that should have an equilibrium near one, it should be reversible. Dr. Ghuysen, can transpeptidation be reversed with artificial substrates? Can the reaction go in the other direction? The energy change is so little in a transpeptidation reaction that the enzyme should catalyze an equilibrium.

DR. GHUYSEN: We have not performed exactly that experiment with a large excess of alanine, but if we take a preparation that hydrolyzes the dimer and incubate it in the presence of large amounts of enzyme it does not return to the initial donor.

DR. STRominger: I don't understand why transpeptidation reactions are not reversible. Although the contribution of the transpeptidation assay is very important, I am not convinced that the excreted Streptomyces enzyme is, in fact, the physiological transpeptidase. Streptomyces would be unique among the six organisms that we have looked at if it has only a single protein sensitive to penicillin. I therefore would guess that the membrane fraction of Streptomyces contains several penicillin-sensitive proteins, including the transpeptidase.

I am totally unconvinced that the membrane transpeptidase and the soluble carboxypeptidase-transpeptidase activity are the same enzyme. The sensitivity profile for inhibition by a variety of penicillins for the excreted enzyme is 
grossly different from the sensitivity profile for the membrane enzyme. My experience with another organism, Bacillus subtilis, suggests that the insertion into the membrane of an enzyme does not change the inhibition by penicillin greatly.

In any case, the question of the relationship of the soluble and membranebound carboxypeptidase-transpeptidases in Streptomyces needs to be elucidated. I think there is no substantial evidence to support the identity of these activities at the present time.

The other question is does penicillin act at an allosteric site or at the substrate site? Dr. Manuel Nieto discussed these experiments in Vienna one month ago. I think he concluded that the evidence from fluorescence studies showed that penicillin might bind either at the donor site or at another site of the enzyme, but the possibility of binding at the acceptor site was excluded.

DR. Ghuysen: Yes, however, he said that with the R-61 Streptomyces enzyme, the addition of the donor to a concentration 10 times the $K_{m}$ value has almost no effect on the binding of benzylpenicillin to the enzyme. I know that there are many explanations, but certainly the most likely conclusion seems to be that the binding sites of the donor and of penicillin are not independent but different. "Not independent" obviously means that there will be some effect, because benzylpenicillin inhibits the enzyme.

Dr. Strominger: Kinetic arguments are very difficult, but I do think that the evidence that the Bacillus stearothermophilus enzyme catalyzes a "penicillinase" activity indicates that penicillin is bound at a catalytic site on the enzyme. The enzyme catalyzes the removal of the penicillin from that enzyme; it is not merely a chemical reaction. Possibly, different enzymes are inhibited in different ways. We have been studying one enzyme, and you and your collaborators have been studying another enzyme. The precise mechanism of inhibition is an interesting problem, but the ultimate answer can only be arrived at by crystallizing a penicillin-sensitive protein with penicillin bound to it, determining how penicillin is bound, and finding out how the substrate is bound. There have already been three decades of work on the mechanism of action of penicillin, and maybe crystallographic studies, which could provide the ultimate answer, will be the fourth decade of investigation.

Dr. GHuYsen: Dr. Strominger, what do you mean by "some penicillinase activity." If you take one mole of pure enzyme and one mole of benzylpenicillin, binding will occur, and in a few hours, benzylpenicillin will be removed from the complex as penicilloic acid. I would not call that a catalytic activity. Assume, for example, that benzylpenicillin is fixed to a sulfhydryl group. It has been shown through study of the allergenic properties of benzylpenicillin that it can form a very stable complex. When your penicillin-Sepharose columns with bound carboxypeptidase are treated with a large excess of benzylpenicillin, is the enzyme protein displaced from the column?

Dr. Strominger: After deacylation, the enzyme can be reacylated by penicillin. In fact, penicillin $G$ is a bad substrate for "penicillinase" activity. With 6-aminopenicillanic acid, the rate of "penicillinase" activity is increased by a factor of about 10 , so the half-time is of the order of one minute or less.

DR. GHUYSEN: With the Streptomyces carboxypeptidase-transpeptidase, we detected no penicillinase activity.

DR. H. G. BomAN: Murein can act as a barrier against penicillin and presumably also against some of the substrates used in a transpeptidation study. This barrier would complicate the interpretation of data obtained with mem- 
brane-bound enzymes present in intact cells. Also, we have isolated penicillinasenegative mutants in $E$. coli. We have studied the alanine carboxypeptidase activity in such strains and have also assayed purified penicillinase for carboxypeptidase activities. Apparently, after using only a limited number of $\mathrm{pH}$ and ionic conditions, there is no evidence for a connection between the penicillinase activity and any of the cell wall enzymes, even autolytic enzymes (see $J$. Bacteriol. 116). 